\title{
Enrichment and distribution of elements in the Late Permian coals from the
}

\section{Zhina Coalfield, Guizhou Province, Southwest China}

\author{
Baoqing $\mathrm{Li}^{1}$, Xinguo Zhuang ${ }^{1}$, Jing $\mathrm{Li}^{1}$, Xavier Querol ${ }^{2}$, Oriol Font ${ }^{2}$, Natalia Moreno ${ }^{2}$ \\ 1 Key Laboratory of Tectonics and Petroleum Resources (China University of Geosciences), Ministry of Education, Wuhan \\ 430074, China \\ 2 Institute of Environmental Assessment and Water Research, CSIC, C/LLuis Solé Sabarís s/n, Barcelona, 08028, Spain
}

\section{Abstract}

This paper investigates the mineralogy and geochemistry of four coal beds (WJB-6, WJB-7, FHS-23 and FHS-27 Coals) of the Late Permian in the Zhina Coalfield, western Guizhou Province, China. The investigated coals reach the semianthracite -anthracite coal rank and have super-low to low ash yields. The sulfur contents vary considerably through coal sections and are mostly in the range of medium-high sulfur coal. The mineral assemblage present in the FHS-23 and FHS-27 Coals is mainly made up of pyrite and rectorite; the WJB-6 and WJB-7 Coals have different mineralogy, with kaolinite and rectorite dominant in the former as well as quartz and rectorite in the latter. These coals contain high concentrations of $\mathrm{Nb}$ and $\mathrm{Ta}$, but $\mathrm{Li}$ is only enriched in the WJB-6 Coal. Rectorite and anatase in these coals are important hosting phases of Nb and Ta while kaolinite, and to a lesser extent chamosite in the WJB-6 Coal, are dominant carriers for the elevated Li occurrence.

The terrigenous material input, the marine influence and the effect of circulating hydrothermal solution are the pivotal geological factors causing geochemical anomalies in coals investigated. The high-sulfur coals were subjected to an enhanced marine influence in the depositional environment, as well as to a higher terrigenous influx, when compared with the medium-sulfur and low-sulfur coals, resulting in higher concentrations of S-Fe-As-Mo-U-Hg in the former coals than in the latter ones. The anomalous enrichment of $\mathrm{Nb}$ and $\mathrm{Ta}$ in these coals, as well as of $\mathrm{Li}$ in the WJB-6 Coal, is the result of the contributions from ascending hydrothermal solutions, although source rocks (e.g., high-Ti basalt) may provide relatively high background abundances of $\mathrm{Nb}$, Ta and Li.

Key words: Geochemistry; Longtan Formation; Late Permian coal; western Guizhou Province

* Corresponding author. Tel./fax: +862767883063

E-mail address: xgzhuang@cug.edu.cn (X. Zhuang).

\section{Introduction}

The anomalous enrichment of some rare-metal elements (e.g., rare earth elements, $\mathrm{Nb}, \mathrm{Zr}, \mathrm{Hf}, \mathrm{Ga}$ ) in the Late Permian tonsteins preserved within coal-bearing strata in southwestern China has been extensively documented by Burger et al. (1990), Dai et al. (2010, 2011, 2014a), Zhao et al. (2017) and Zhou et al. (2000) and references therein. However, the tonstein-hosted rare-metal deposits attracted little attention as raw materials of rare metal recovery, due to the thin thickness (generally 3-10 cm) of intraseam tonstein layer (Dai et al., 2016a; Hower et al., 2015a; Seredin and Dai, 2012), but it probably provides a basis for predicting the occurrence of tuffaceous polymetallic deposit of volcanic ash outside of coal seams (Dai et al., 2011; Seredin and Finkelman, 2008). For example, linked to tonstein studies, Dai et al. (2010) found the $\mathrm{Nb}-\mathrm{Zr}$-REE-Ga polymetallic mineralization in tuffaceous horizons with thickness up to $10 \mathrm{~m}$ in eastern Yunnan Province, and subsequently, such rare-metal deposits were investigated by Zhao et al. (2016a, 2016b, 2017). Meanwhile, the Late Permian coals in southwestern China are also reported as having the highly-elevated concentrations of REEs, Nb and Zr in the Huayingshan Coalfield (Zhuang et al., 2012; Dai et al., 2014b), Songzao Coalfield (Dai et al., 2007a), Guxu Coalfield (Dai et al., 2016b), and Moxinpo Coalfield (Dai et al., 2017), and of Ti, Nb and Ta in the Liuzhi Coalfield (Li et al., 2016), as well as of U-Mo-V-Cr-Co in the Yanshan, Heshan, Guiding and Moxinpo Coalfields (Dai et al., 2008a, 2012a, 2013, 2015a, 2016a, 2017; Liu et al., 2015; Shao et al., 2003; Zeng et al., 2005). Recently, Dai et al. (2016c) 
outlined the geological distribution of the highly-elevated rare-metal elements in the Late Permian coals and tonsteins in the southwestern China, and found that their spatial distributions surround closely the Emeishan Large Igneous Province as described by He et al. (2006), suggesting that the highly-elevated concentrations of rare-metal elements are in association with the evolution of the Emeishan mantle plume (Dai et al., 2016c). Additionally, coal-hosted rare metal ore deposits in other areas around the world have also attracted much attention and have been investigated by Blissett et al. (2014), Crowley et al. (1989), Hower et al. (1999, 2015b, 2016), Hower and Dai (2016), Mayfield and Lewis (2013), Rozelle et al. (2016).

The Late Permian coals in western Guizhou Province, southwestern China, are found as being remarkably enriched in specific trace elements, including $\mathrm{Cu}, \mathrm{U}, \mathrm{Mo}$ and $\mathrm{Zr}$ of a major volcanic ash origin in the Zhijin Coalfield (Dai et al., 2003, 2004), and Nb and Ta of detrital origin in the Liuzhi Coalfield (Li et al., 2016; Zhuang et al., 2000), together with $U$ in intimate association with organic matter in the Guiding and Ziyun Coalfields (Dai et al., 2016a; Liu et al., 2015). In a recent study, we found anomalous enrichments of $\mathrm{Li}, \mathrm{Nb}$ and $\mathrm{Ta}$ in the Late Permian coals of the Zhina Coalfield in western Guizhou Province, China. The enrichment of $\mathrm{Li}$ has been reported worldwide in a few Coalfields, such as the Krylovsk and Verkhne-Bikinsk Coalfields in Russian Far East (Seredin et al., 2013) and the Junger Coalfield in northern China (Dai et al., 2008b, 2012b; Sun et al., 2010, 2012). However, as far as the author knowledge, the high concentrations of $\mathrm{Li}$ in the Late Permian coals in southwestern China have not been previously documented. In this paper, we report the major mineralogical and geochemical patterns of the Late Permian coals in the Zhina Coalfield and discuss the geological factors causing geochemical anomalies for specific trace elements.

\section{Geological setting}

The Guizhou Province is located in the southwestern China (Fig. 1A) and has abundant coal resources. Tectonically, the western Guizhou Province is situated in the western portion of Yangtze Continental Block, and is bounded by Kangdian Upland to the west, South China Caledonian Orogenic Belt to the south and Jiangnan Ancient Continent to the east (Fig. 1B; Shao et al., 2013). The Zhina Coalfield is located in the western Guizhou Province (Fig. 1C).

The coal-bearing strata in the Zhina Coalfield include the Longtan and Wangiazhai Formations, all of which are of the Late Permian age (Xu and He, 2003). The Longtan Formation, which overlies unconformably the Middle Permian Maokou Formation and underlies conformably the Wangjiazhai Formation, consists mainly of fine-sandstone, siltstone, silty mudstone, mudstone, and interbedded limestone layers as well as minable and non-workable coal seams (Fig. 2). It has a thickness of 196 to 320 $\mathrm{m}$ and contains nine to thirty-five coal seams, of which Nos. 7, 16, 21, 23 and 27 coal seams are the main minable ones. The No.7 coal seam, with an average thickness of $1.76 \mathrm{~m}$, is situated in the uppermost Longtan Formation and has a roof strata of marine origin (limestone) (Fig. 2), indicating that seawater flooded the peat swamp and terminated the peat accumulation. The Nos.23 and 27 coal seams are located in the lower section of the Longtan Formation and were formed in a tidal flat-lagoon environment frequently subjected to seawater influx (Fig. 2).

The Wangjiazhai Formation, the subordinate coal-bearing unit, is overlain by the early Triassic Feixianguan Formation and is mainly composed of sandstone, siltstone and limestone layers. It has a thickness of 64 to $165 \mathrm{~m}$, and contains a minable coal seam (No. 6 coal seam) (Fig. 2). The No.6 coal seam, with an average thickness of $2.47 \mathrm{~m}$, is located in the lowermost section of the Wangjiazhai Formation and was deposited in a lower-deltaic plain environment (Fig. 2).

The Kangdian Upland, which is located to the west of Guizhou Province (Fig. 1C), and mainly built by 
the Emeishan basalt, serves as the dominant sediment-source region for the Late Permian coals in the southwestern China (China Coal Geology Bureau, 1996; Dai et al., 2016b). The Emeishan basalt is mainly composed of low-Ti and high-Ti flood basalts (Xiao et al., 2004; Xu et al., 2001), with numerous coeval alkaline mafic lavas, mafic-ultramafic intrusions and granitic and syenitic plutons (Wang et al., 2015; Xiao et al., 2004; Zhou et al., 2008). The felsic-intermediate volcanics located in the uppermost section of the Emeishan basalt could have been a major terrigenous source rock for the lowermost coals in the Late Permian strata in the Guxu and other Coalfields in southern Sichuan Province (Dai et al., 2016b). The volcanic ash falls derived from a rhyolitic-rhyodacitic magma source may be another source contribution of mineral matter and associated trace elements to the Late Permian coal-bearing strata (Isozaki et al., 2004; Zhou et al., 2000). Additionally, the Middle Permian Maokou Formation limestone may have been an important source rock for the Late Permian coal basins in southwestern China (He et al., 2006; Wang et al., 2012). However, the Emeishan basalt, rather than other source rocks mentioned above, serves as principal source of detrital supply for most of the Late Permian coals in southwestern China.

\section{Methodology}

A total of thirty-one bench samples were obtained from the Late Permian coals in the Fenghuangshan and Wenjiaba underground coal mines of the Zhina Coalfield, western Guizhou Province, China (Fig. 1C). These include six, six and seven coal benches from the No.23-1, No.23-2 and No.27 Coal seam sections (identified as FHS-23-1 Coal, FHS-23-2 Coal and FHS-27 Coal), respectively, in the Fenghuangshan underground coal mine (Fig. 3). The No.23-1 and No.23-2 Coals are the same coal seam but samples are collected from different coal seam sections, and thus identified as FHS-23 Coal. Seven coal benches were collected from the No. 6 Coal (identified as WJB-6 Coal) in the Wenjiaba underground coal mine (Fig. 4). Five samples including four coal benches and one carbonaceous mudstone were obtained from the No. 7 Coal (identified as WJB-7 Coal) in the Wenjiaba underground coal mine (Fig. 4).

Proximate analysis was conducted using ASTM Standards D3173-11, D3175-11, and D3174-11 (2011). A field emission-scanning electron microscope (FE-SEM, FEI Quanta ${ }^{\mathrm{TM}} 650 \mathrm{FEG}$ ), coupled with an energy-dispersive X-ray spectrometer (EDAX; Genesis Apex 4), was used to study the morphology and composition of minerals. Mineralogical analyses of the coal samples were performed by means of Powder $\mathrm{X}$-ray Diffraction (XRD) using a Bruker D5005 diffractometer with monochromatic $\mathrm{Cu} \mathrm{K \alpha}$ radiation operated at $40 \mathrm{kV}$ and $40 \mathrm{~mA}$, scanning from 4 to $60^{\circ} 2$ theta with a step size of $0.05^{\circ}$ and a counting time of $3 \mathrm{~s} / \mathrm{step}$. Semi-quantitative XRD analysis was performed by using the Reference Internal Standard Method (Chung, 1974), with the results for mineral content being presented on dry and whole coal basis.

Samples were crushed and ground to pass 200 mesh $(75 \mu \mathrm{m})$ for geochemical analysis and were first acid-digested following a two-step digestion method devised to retain volatile elements in solution (Querol et al., 1997). Inductively Coupled Plasma Atomic-Emission Spectrometry (ICP-AES, Iris Advantage TJA Solutions) was used to determine major element concentrations and Inductively Coupled Plasma Mass Spectrometry (ICP-MS, X-Series II Thermo) for trace elements. Blank samples and digestion of international reference materials (SARM-19) were also carried out following the same procedure to check the accuracy of the digestion and the analytical methods. The analytical precision were better than $\pm 3.5 \%$ for $\mathrm{Si}, \mathrm{Al}, \mathrm{Fe}, \mathrm{Mg}, \mathrm{V}, \mathrm{Be}, \mathrm{Zr}$, Dy, Er and Th, and better than $\pm 5.0 \%$ for $\mathrm{K}, \mathrm{Ca}, \mathrm{Ti}, \mathrm{Mn}, \mathrm{Co}, \mathrm{Mo}, \mathrm{Ba}, \mathrm{Cr}, \mathrm{Pr}$, $\mathrm{Gd}, \mathrm{Y}, \mathrm{Nd}$, and $\mathrm{Pb}$, and better than $\pm 10.0 \%$ for the remaining major and trace elements. Mercury concentrations in coal samples were determined by atomic absorption spectrometry with gold amalgam in an AMMA 284.

\section{Results}

\subsection{Coal chemistry}


The moisture contents of the Late Permian coals studied from the Zhina Coalfield range from $2.29 \%$ to $3.60 \%$, with an average of $2.98 \%$ (Table 1). The volatile matter yield in the low-ash coals (coal with less than $20.0 \%$ ash yield), which ranges from $4.9 \%$ to $12.0 \%$ (with an average of $7.3 \%$ ), falls within the range of semianthracite-anthracite (2-14\% for semianthracite-anthracite; ASTM D388-12, 2012) in accordance with the previous researches as documented by $\mathrm{Xu}$ and $\mathrm{He}$ (2003). The investigated coals are characterized by super-low to low ash yields except for three samples (FHS23-2-3, FHS27-3 and WJB7-2) with medium to medium-high ash yields (Table 1) according to Chinese Standards GB/T 15224.1-2010 (Ash yield <10\% for special-low ash coal, 10-20\% for low ash coal, 20-30\% for medium ash coal, 30-40\% for medium-high ash coal). Additionally, the sample WJB7-1-C obtained from the WJB-7 Coal in the Wenjiaba underground coal mine has an ash yield $>50.0 \%(54.1 \%)$ and thus should be classified as carbonaceous mudstone (Damberger et al., 1984).

The FHS-23 Coal is dominated by medium-sulfur coal (1-3\% for medium-sulfur coal; Chou, 2012), with the exception of one sample (FHS23-1-6) being a low-sulfur coal $(<1.0 \%$ for low-sulfur coal; Chou, 2012) and three samples (FHS23-1-1, FHS23-2-1 and FHS23-2-3) identified as high-sulfur coals $(>3.0 \%$ for high-sulfur coal; Chou, 2012) (Table 1). The FHS-27 Coal varies considerably in sulfur content from $1.45 \%$ to $12.57 \%$, with a mean of $3.84 \%$. The WJB-6 Coal has sulfur contents varying between $0.74 \%$ and $1.87 \%$ ( $1.25 \%$ on average), with medium-sulfur coals dominating. The WJB-7 Coal varies considerably in sulfur content in the range of $0.54 \%$ to $7.03 \%$, with high sulfur content in the uppermost (samples WJB7-1-C, WJB7-2) and lowermost (WJB7-5) coal benches, and low sulfur content $(<1.0 \%)$ in the middle coal benches (WJB7-3, WJB7-4) (Table 1).

\subsection{Mineralogical patterns}

\subsubsection{Mineralogical compositions}

The percentage of each crystalline phase identified by XRD analysis of the coal benches and carbonaceous mudstone samples is given in Table 2. The major minerals in the FHS-23 and FHS-27 Coals are pyrite $(5.0 \%$ and $6.6 \%$ on average, respectively) and rectorite ( $4.1 \%$ and $3.6 \%$, respectively), with lesser but considerably varying amounts of quartz (Fig. 3). Trace to minor amounts of palygorskite, anatase and gypsum occur in some of samples. Ankerite in minor amount $(3.7 \%)$ only occurs in one sample (FHS23-2-2), while calcite in minor to trace amounts occurs in two samples (Fig. 3).

The WJB-6 Coal mineral assemblage is mainly made up of kaolinite (4.8\%) and rectorite (3.0\%), and to a lesser extent quartz (2.1\%) and pyrite (1.3\%), with trace amounts of calcite $(0.4 \%)$, anatase $(0.1 \%)$ and gypsum $(0.1 \%)$ (Fig. 4). The mineral assemblage of the WJB-7 Coal mainly comprise quartz $(8.5 \%)$ and rectorite $(4.0 \%)$, and to a lesser extent pyrite $(1.4 \%)$, along with trace amounts of calcite $(0.5 \%)$, anatase $(0.1 \%)$ and gypsum $(0.1 \%)$ (Fig. 4). Montmorillonite is only detected in one sample (WJB7-2) but makes up $29 \%$ of total mineral content. The carbonaceous mudstone, directly overlying the WJB-7 Coal, is mainly composed of quartz (31.9\%), and to a lesser extent of rectorite (8.4\%), pyrite (5.0\%) and montmorillonite (5.0), with trace to minor amounts of anatase (2.3\%), chlorite $(0.8 \%)$ and gypsum $(0.6 \%)$.

\subsubsection{Vertical distribution of minerals}

The mineralogical composition in coal is influenced by complex geological factors (Swaine and Goodarzi, 1995). However, the same coal seam most commonly has a similar mineral assemblage (Rao and Walsh, 1999). As shown above, three mineral assemblages are identified in the studied coals, including pyrite-rectorite assemblage prevailing in the FHS-23 and FHS-27 Coals (Fig. 3), kaolinite-rectorite-quartzpyrite in the WJB-6 Coal and quartz-rectorite in the WJB-7 Coal. These similar mineral assemblages possibly indicate a similar detrital influx, diagenesis or hydrothermal activity (Dai et al., 2015b).

Quartz is the most abundant constituent in some samples adjacent to the parting, roof and floor of coal 
seams and shows trace to minor amounts in the remainder of coal seams (Figs. 3, 4). Furthermore, the content of quartz increases with ash yield of the samples studied (Fig. 5A), probably indicating more influx of terrigenous source material (as detrital material or ionic and colloidal forms) into peat swamp (Li et al., 2016). However, quartz, making up relatively high proportions (22-69\%) of total mineral matter in some samples, may have been of authigenic origin (rather than detrital one) due to the low quartz contents in the Emeishan basalt source rock. Actually, authigenic quartz is the most commonly observed in the Late Permian coals and in some cases, in host rocks (Dai et al., 2012a, 2016b, c). As an example, Dai et al. (2016b) reported that the high amounts of quartz in the roof strata are of an authigenic origin and derived from silicon-bearing solution from leaching of the Emeishan basalt (Ren, 1996) or post-depositional hydrothermal solution (Dai et al., 2012a).

Anatase, in some cases, show strikingly similar vertical distribution to quartz (Figs. 3, 4) and increases with ash yield in samples studied (Fig. 5B), suggesting that terrigenous material input most likely controls its distribution.

Kaolinite is mainly present in the WJB-6 Coal, with trace amounts in the WJB-7 Coal (Fig. 4). Kaolinite content is below the XRD detection limit in the samples WJB7-1-C and WJB7-2, near the roof strata (limestone) of marine origin (Fig. 4). Possible cause for this upward decrease is that the progressively increasing seawater influence resulted in an increase of alkalinity that in turn lowered solubility of $\mathrm{Al}$ from peat swamp as reported by Ward (2016).

Pyrite is the only Fe disulfide found by XRD means in the samples investigated. Pyrite is the most abundant in the FHS-23 and FHS-27 Coals, and accounts for $22.2 \%$ to $84.3 \%$ of total mineral contents, respectively, indicating that the peats of these coal seams are accumulated under a seawater-influenced depositional environment; since pyrite formation needs abundant supply of seawater sulfate. Pyrite in the WJB-6 Coal is present in lower concentrations, but still reaching $10.8 \%$ of total mineral matter. Pyrite contents are relatively high in the upper benches (WJB7-1-C and WJB7-2) and lower coal bench (WJB7-5) but this matter was not detected by XRD analysis in the middle coal benches (WJB7-3 and WJB7-4) in the WJB-7 Coal (Fig. 4), indicating probably a higher degree of seawater influence on the initial and ending stages of peat accumulation.

\subsubsection{The modes of occurrence of minerals}

Pyrite occurs in the following forms, as (1) spherical polycrystalline framboidal pyrite (Fig. 6A); (2) cell infillings of structured macerals, in some cases, coexisting with rectorite (Figs. 6E, 7A) and with Fesulfate species (Fig. 7C); (3) disseminated pyrite in the pores of organic matrix (Figs. 6B, 6C, 8A, 8D); (4) needle-like pyrite (Fig. 6F); (5) massive pyrite (Fig. 8D); (6) cleat or fracture-filling pyrite (Fig. 7E). The former five modes of occurrence of pyrite are indicative of a syngenetic or early-diagenetic origin and, thus, its content can largely represent depositional environment immediately following peat accumulation or shortly after peat formation. However, the latter mode (6) is of an epigenetic hydrothermal origin (Kolker et al., 2012). Framboidal pyrite is commonly formed through multiple sulfide phases from iron monosulfide (FeS) to mackinawite $\left(\mathrm{FeS}_{0.9}\right)$ to greigite $\left(\mathrm{Fe}_{3} \mathrm{~S}_{4}\right)$ and to framboidal pyrite $\left(\mathrm{FeS}_{2}\right)(\mathrm{Chou}, 1990,2012)$ during early diagenesis (Diehl et al., 2004; Kolker et al., 2012) while single euhedral pyrite crystal may have formed from reaction of $\mathrm{FeS}$ with polysulfides (Luther, 1991) during peat accumulation to early diagenesis or is precipitated directly by reaction of $\mathrm{Fe}^{2+}$ with elemental sulfur $\left(\mathrm{S}^{0}\right)$ as reported by Chou $(1990,2012)$.

Fe sulfate or Fe-oxysulfate, although below the detection limit of XRD analysis, is observed by SEM-EDX in the present study. It occurs as massive form in the cavity of collodetrinite (Fig. 6B, 6C), as cell fillings rounding cell-filling pyrite (Fig. 7C). Fe sulfate minerals are commonly considered to be derived from oxidation of Fe-sulfide mineral (e.g., Chou, 2012; Rao and Gluskoter, 1973; Ward, 2002, 
2016). In some cases, Fe sulfate mineral keeps the shape of pyrite crystal (Fig. 6C) and surrounds pyrite crystals (Fig. 7C), which provides direct evidence that Fe sulfate is directly originated from oxidation of Fe-sulfide mineral. The cell-filling Fe sulfate represents the artefact caused by oxidation of cell-filling Fe-sulfide phase and thus suggests an epigenetic origin rather than syngenetic origin.

Rectorite is less abundant in previous evaluations of the Late Permian coals in the western Guizhou Province (e.g., Dai et al., 2003, 2004; Li et al., 2016; Zhuang et al., 2000). However, rectorite occurs largely in the investigated samples. Rectorite mainly occurs as (1) cell-filling rectorite (Figs. 6E, 7A); (2) cleat-filling rectorite (Figs. 7D, 7E). The cell-filling rectorite is indicative of a syngenetic origin while cleat/fracture infillings are of an epigenetic origin.

Gypsum occurs as lath-like subhedral to euhedral crystals nearing fracture/cleat in the organic matrix (Fig. 8D). This mineral is most commonly formed by weathering of minerals (Rao and Gluskoter, 1973; Ward, 2002, 2016). The gypsum crystals near fracture/cleats (Fig. 8D), together with the presence of Fe sulfate from oxidation of pyrite, presumably indicate that gypsum is generated by reaction between calcite and sulfuric acid produced by oxidation of pyrite in the investigated samples.

Chlorite is not a common mineral in the Late Permian coals in the southwestern China and generally makes up a minor proportion of total mineral matter. Chlorite, although below detection limit by XRD analysis, is observed by SEM-EDX. It mainly occurs as cleat infillings (Figs. 8A, 8C), indicating an epigenetic origin. The SEM-EDX data show a high amount of Fe but low $\mathrm{Mg}$ in chlorite and thus it is classified as chamosite (Fig. 8B). The previous studies concluded that chamosite is unstable in acidic freshwater swamp environment (Rao and Gluskoter, 1973) and slight alkaline $\mathrm{pH}$ is required for its formation (Dai et al., 2007b). Chamosite may be formed in association with rank advance processes (Permana, 2011; Permana et al., 2013; Susilawati and Ward, 2006; Vassilev and Vassileva, 1996), possibly by reaction of kaolinite and Fe-Mg rich hydrothermal solution (Sanguesa et al., 2000; Wang et al., 2013), and of smectite and K-Al rich fluid (Permana, 2011). The cleat/fracture infillings of chamosite in the investigated samples may be the result of reaction of rectorite and Fe-Mg rich hydrothermal solution derived from the weathering of Emeishan basalts as previously reported by Dai et al. (2008c) and Wang et al. $(2012,2013)$.

\subsection{Geochemistry}

\subsubsection{Major-element oxides}

The percentages of major-element oxides and concentrations of trace elements in the samples from the Zhina Coalfield are listed in Tables 3-5. The averaged elemental contents for the WJB-6, WJB-7, FHS-23 and FHS-27 Coals as well as the carbonaceous mudstone sample (WJB7-1-C) from the WJB-7 Coal, together with those of the coals from western Guizhou Province (Dai et al., 2005), Chinese coals (Dai et al., 2012a) and world hard coals (Ketris and Yudovich, 2009) for comparison, are also compiled in Table 6. The percentages of the major-element oxides in coal samples are similar to or much lower than the corresponding averages for western Guizhou coals (Dai et al., 2005), due to relatively low ash yield (12.6\% on average). The $\mathrm{SiO}_{2}, \mathrm{TiO}_{2}, \mathrm{Al}_{2} \mathrm{O}_{3}, \mathrm{Fe}_{2} \mathrm{O}_{3}, \mathrm{MgO}$ and $\mathrm{K}_{2} \mathrm{O}$ concentrations in the carbonaceous mudstone sample (WJB7-1-C) are two-thirteen times higher than corresponding ones in the WJB-6, WJB-7, FHS-23 and FHS-27 Coals, owing mainly to its high ash yield (54.1\%) (Table 1). $\mathrm{The}^{\mathrm{SiO}} \mathrm{S}_{2} / \mathrm{Al}_{2} \mathrm{O}_{3}$ ratios in the WJB-6 (1.8 on average), FHS-23 (1.6) and FHS-27 (1.5) Coals are similar to theoretical ratio for kaolinite (1.2), while $\mathrm{SiO}_{2} / \mathrm{Al}_{2} \mathrm{O}_{3}$ ratio in the WJB-7 Coal (6.9) is significantly higher than that in kaolinite (1.2), indicating the more occurrence of free $\mathrm{SiO}_{2}$ in the WJB-7 Coal, which is in accordance with the relatively high amounts of quartz in the WJB-7 Coal (Table 2).

The positive linear correlations of $\mathrm{K}_{2} \mathrm{O}-\mathrm{Al}_{2} \mathrm{O}_{3}$ ( $\mathrm{r}=0.78$; Fig. 5C), $\mathrm{TiO}_{2}-\mathrm{Al}_{2} \mathrm{O}_{3}$ ( $\mathrm{r}=0.76$; Fig. 5D), 
$\mathrm{MgO}-\mathrm{Al}_{2} \mathrm{O}_{3}\left(\mathrm{r}=0.70\right.$; Fig. 5E) and $\mathrm{Na}_{2} \mathrm{O}-\mathrm{Al}_{2} \mathrm{O}_{3}(\mathrm{r}=0.64$; Fig. 5F) indicate that these mainly occur in aluminosilicate phases. Fe and sulfur exhibit a significant correlation ( $r=1.0)$ in the samples (Fig. 5G), suggesting that both are predominantly associated with $\mathrm{Fe}$ disulfide (e.g., pyrite) as evidenced by significantly positive correlations of S-pyrite $(\mathrm{r}=0.92)$ and $\mathrm{Fe}$-pyrite $(\mathrm{r}=0.91)$. In the bivariate plot of $\mathrm{Fe}$ versus sulfur (Fig. 5G), the slope of regression line is 0.91 extraordinarily comparable to the theoretical $\mathrm{Fe} / \mathrm{S}$ ratio (0.87) in pyrite crystalline structure, indicating that $\mathrm{Fe}$ and sulfur most exclusively occur as pyrite. However, the regression line intersects with sulfur axis at a point (sulfur=0.34\%), suggesting that the content of other forms of sulfur (e.g., organic and sulfate sulfur) is approximate $0.34 \%$.

\subsubsection{Trace elements}

The concentration coefficient (CC) used in the present study is the ratio of element concentration in the investigated coals versus referenced coals (e.g., world hard coals or Chinese coals), with CC value less than 0.5, 0.5-2.0, 2.0-5.0, 5.0-10 and 10-100 indicative of depletion, similarity, slight enrichment, enrichment and significant enrichment, respectively (Dai et al., 2016d). Compared with world hard coals reported by Ketris and Yudovich (2009), the enriched elements in the samples investigated include $\mathrm{Li}, \mathrm{Nb}$ and $\mathrm{Ta}$ in the WJB-6 Coal, Nb and Ta in the WJB-7 Coal, Li, V, Zr, Nb, Mo and Ta in the FHS-23 Coal as well as Li, V, $\mathrm{Zr}, \mathrm{Nb}, \mathrm{Mo}$, Ta and U in the FHS-27 Coal (Fig. 9). In particularly, the CC for Ta is as high as 18 and 26 in the WJB-6 and WJB-7 Coals, respectively. However, the concentrations of the remaining trace elements are comparable to or lower than the averages for world hard coals. The carbonaceous mudstone directly overlying the WJB-7 Coal has higher concentrations of trace elements (except for Mo) than other coals, indicating that more input of terrigenous source material is responsible for the enrichment of some trace elements.

Significant correlations with $\mathrm{Al}$ are determined for $\mathrm{Sc}, \mathrm{Cr}, \mathrm{Co}, \mathrm{Ga}, \mathrm{Rb}, \mathrm{Sr}, \mathrm{Nb}, \mathrm{Sn}, \mathrm{Ba}, \mathrm{Hf}, \mathrm{Ta}$ and $\mathrm{Th}$ $(\mathrm{r}=0.71-0.92)$, indicating that these elements are housed chiefly in aluminosilicate phases. The more significant linear correlation of $\mathrm{Rb}-\mathrm{K}_{2} \mathrm{O}(\mathrm{r}=0.99)$ than $\mathrm{Rb}-\mathrm{Al}_{2} \mathrm{O}_{3}$ ( $\left.\mathrm{r}=0.78\right)$ suggests that K-bearing minerals (e.g., illite, rectorite) control on $\mathrm{Rb}$ is presumably more pivotal than other aluminosilicate minerals. This may result from that $\mathrm{K}$ and $\mathrm{Rb}$ have similar ionic radius and thus $\mathrm{Rb}$ can more easily substitute for $\mathrm{K}$ than $\mathrm{Al}$ in aluminosilicate phases (Degens et al., 1957). The $\mathrm{Zr} / \mathrm{Hf}$ ratios (59-3880, 514 on average) in coal samples are remarkably higher than that in zircon (30-40) proposed by Murali et al. (1983), indicating that zircon is not a major carrier for $\mathrm{Zr}$ and more free $\mathrm{Zr}$ may occur in other minerals, such as clay mineral and anatase. The relatively significant correlation between $\mathrm{Mn}$ and $\mathrm{CaO}(\mathrm{r}=0.67)$ suggests that carbonate minerals are important in hosting the $\mathrm{Mn}$, which is in accordance with previous investigations in coals (Finkelman, 1994; Swaine, 1990). The significant correlations of As-sulfur (Fig. 5H) and Hg-sulfur (Fig. 5I) indicate a dominant sulfide affinity because both As and $\mathrm{Hg}$ can enter pyrite structure by substitution for sulfur or iron ion (Kolker et al., 2012). Actually, a sulfide affinity of As and $\mathrm{Hg}$ in western Guizhou coals has been also reported by Dai et al. (2005) and Zhuang et al. (2000).

\subsubsection{Rare earth elements (REEs) and yttrium}

The classification and enrichment types of REEs and Y (REY, or REE if yttrium is not included) proposed by Seredin and Dai (2012) are used in the present study. The concentrations of REY in the WJB-6, WJB-7, FHS-23 and FHS-27 Coals are 70, 79, 82 and $80 \mu \mathrm{g} / \mathrm{g}$, respectively, which are comparable to the average for the world hard coals (68 $\mu \mathrm{g} / \mathrm{g}$; Ketris and Yudovich, 2009), but much lower than the average for Chinese coals (136 $\mu \mathrm{g} / \mathrm{g}$; Dai et al., 2012a). Given the low ash yields in coals investigated, the concentrations of REY in coal ashes investigated range from 205 to $1602 \mu \mathrm{g} / \mathrm{g}$, with an average of $677 \mu \mathrm{g} / \mathrm{g}$ much higher than that for the low-Ti basalts (106 $\mu \mathrm{g} / \mathrm{g}$; Xiao et al., 2004) and high-Ti basalts $(286 \mu \mathrm{g} / \mathrm{g}$; Xiao et al., 2004). However, the REY content $(275 \mu \mathrm{g} / \mathrm{g})$ in the carbonaceous mudstone ash (sample 
WJB7-1-C) is close to the average for high-Ti basalts ( $286 \mu \mathrm{g} / \mathrm{g}$; Xiao et al., 2004). These appear to imply that, besides the terrigenous source material from the Emeishan basalt, REY in coals investigated may have additional sources. The Upper Continental Crust (UCC; Taylor and McLennan, 1985)-normalized REY patterns of the investigated coals and carbonaceous mudstone show the M-type (Seredin and Dai, 2012) REY distribution patterns and positive Eu anomalies (Fig. 10), possibly indicating a joint influence of the Emeishan basalt and hydrothermal solution for REY distribution.

\section{Discussion}

\subsection{Coal geochemistry and depositional environment}

It is well known that sulfur content in coal is closely associated with coal-forming environment immediately following or shortly after peat accumulation (Chou, 1990, 2012), although elevated sulfur contents in some coals are derived from hydrothermal solutions or volcanoclastic materials (Dai et al., 2015a; Whateley and Tuncali, 1995). Commonly, coals that have been subjected to seawater invasion have higher sulfur content than those deposited in freshwater environments (Casagrande et al., 1987; Chou, 2012), indicating a greater availability of seawater sulfate (Chou, 2012; Dai et al., 2015a). In the present study, the WJB-7 Coal has roof strata of marine origin (Fig. 4) and the uppermost layer (WJB7-1-C) has the highest sulfur content relative to other coal benches, indicating a distinct seawater infiltration into the underlying coal seam. The sulfur contents in the FHS-23, FHS-27, WJB-6 and WJB-7 Coals reach $2.86 \%$, $3.84 \%, 1.25 \%$ and $3.24 \%$, respectively, suggesting that the FHS-23, FHS-27 and WJB-7 Coals were deposited in a greatly seawater-influenced environment while the WJB-6 Coal was deposited under an environment with diminished seawater influence. Meanwhile, the similar mineral assemblage (pyrite-rectorite) and element assemblage (Li-V-Zr-Nb-Ta-Mo-U) in the FHS-23 and FHS-27 Coals possibly indicate that both have been subjected to similar geological processes during coalification.

The sulfur content varies considerably throughout coal sections, indicating variable degrees of seawater influence during or shortly after peat accumulation. For example, the lower (sample WJB7-5), middle (WJB7-3, WJB7-4) and upper portions (WJB7-2) of the WJB-7 Coal have 3.0\%, 0.55\% and 6.05\% sulfur contents, respectively, indicating a more significant seawater influence on the lower and upper sections than middle section of the WJB-7 Coal. In the present study, coal with high sulfur content most commonly occurs in the coal benches adjacent to parting, host rocks of coal seam while coal with relatively low sulfur content in the remainder of coal seam. This sulfur distribution is a combination of seawater infiltration and input of terrigenous source material. First, seawater infiltrated into peat and provided abundant $\mathrm{SO}_{4}{ }^{2-}$ that was then converted to $\mathrm{H}_{2} \mathrm{~S}$; second, the influx of Fe-rich detritus or surface water from sediment-source region into peat swamp can supply abundant Fe. As a result, the $\mathrm{H}_{2} \mathrm{~S}$ may react with $\mathrm{Fe}$ to form Fe-sulfide phases. The pyrite content increases with total sulfur $(\mathrm{r}=0.99)$, indicating abundant $\mathrm{Fe}$ supply during peat accumulation. Thus, pyrite formation primarily depends on the abundance of seawater $\mathrm{SO}_{4}{ }^{2-}$ due to abundant supply of Fe-rich detritus and solution from sediment-source region during peat accumulation.

The difference of seawater influence on peat-accumulating environment results in various geochemical patterns for the investigated coals. A comparison of trace elements abundances among high-sulfur $(>3.0 \%$ sulfur content), intermediate-sulfur (1-3\%) and low-sulfur coals $(<1.0 \%)$ shows that the high-sulfur coals have the highly-elevated concentrations of S-Fe-As-Mo-U-Hg relative to intermediate and low-sulfur coals, indicating that the influx of seawater into peat plays an important role for their enrichment. Commonly, the elements (e.g., S, Mo and $\mathrm{U}$ ) are most commonly derived from seawater, while elements such as $\mathrm{Fe}$ and $\mathrm{Hg}$ are supplied by sediment-source region, and thus the elevated concentrations of S-Fe-As-Mo-U-Hg are the result of combined influence of marine invasion and terrigenous material input. This assemblage (S-Fe-As-Mo-U-Hg) in the high-sulfur coals investigated is different to that (S-V-Cr-Se-Mo-Cd-Re-U) of 
superhigh-organic-sulfur (SHOS) coals formed in sulfur-rich and iron-poor environments (Dai et al., 2015a; Liu et al., 2015). By contrast, this assemblage of S-Fe-As-Mo-U-Hg in the present study indicates sulfur-rich and Fe-rich coal-forming environments.

The Ni contents significantly positively correlates with sulfur ( $\mathrm{r}=0.95)$ in the FHS-27 Coal except one sample (FHS27-3) (Fig. 5J) having the highest sulfur content (12.57\%) but relatively low Ni content (6.7 $\mu \mathrm{g} / \mathrm{g}$ ). The highest sulfur content in the sample FHS27-3 is accompanied by the elevated As and $\mathrm{Hg}$ abundances, but relatively depleted $\mathrm{Ni}$ and $\mathrm{Pb}$ concentrations, suggesting that the elevated $\mathrm{As}$ and $\mathrm{Hg}$ in sample FHS27-3 are probably incorporated into epigenetic pyrite (e.g., cleat/fracture-filling pyrite), since epigenetic pyrite most commonly has elevated concentrations of As and $\mathrm{Hg}$ but depleted $\mathrm{Ni}$ and $\mathrm{Pb}$ concentrations as reported by Diehl et al. $(2004,2012)$ and Kolker et al. (2012).

The significant linear correlations between $\mathrm{U}$ and $\mathrm{Mo}(\mathrm{r}=0.96$; Fig. $5 \mathrm{~K}$ ) as well as among $\mathrm{As}, \mathrm{Hg}$ and $\mathrm{Pb}(\mathrm{r}=0.77-0.87)$ in the investigated coals suggest a similar geochemical behavior, respectively. The relatively low As $(3.1 \mu \mathrm{g} / \mathrm{g}), \mathrm{Hg}(0.16 \mu \mathrm{g} / \mathrm{g})$ and $\mathrm{Pb}(5.4 \mu \mathrm{g} / \mathrm{g})$ but high sulfur content $(2.8 \%)$ in the studied coals indicate that these elements are most likely hosted by syngenetic pyrite (e.g., framboidal pyrite, cell-filling pyrite) rather than epigenetic pyrite (e.g., cleat/fracture-filling pyrite) as the former generally contains these trace elements at normal concentration, whereas the latter at higher concentration (Diehl et al., 2004, 2012; Kolker et al., 2012).

\subsection{The elements enriched in coals}

\subsection{1 lithium}

The WJB-6 Coal has elevated concentrations of $\mathrm{Li}$, in the range of 87.0 to $185.2 \mu \mathrm{g} / \mathrm{g}$, with an average of $117.5 \mu \mathrm{g} / \mathrm{g}$ which is 9.8 and 3.7 times higher, respectively, than the average values for world $(12 \mu \mathrm{g} / \mathrm{g}$; Ketris and Yudovich, 2009) and Chinese coals (31.8 $\mu \mathrm{g} / \mathrm{g}$; Dai et al., 2012a). The average Li content in WJB-6 Coal is similar to that in the Haerwusu coals (116 $\mu \mathrm{g} / \mathrm{g}$; Dai et al., 2008b) but is lower than that in the Guanbanwusu coals (175 $\mu \mathrm{g} / \mathrm{g}$, Dai et al., 2012b; $264 \mu \mathrm{g} / \mathrm{g}$, Sun et al., 2012). Li is enriched in the latter two previously investigated coals. Li content varies distinctly throughout the WJB-6 Coal section and shows higher values in the lowermost (sample WJB6-7) and middle coal benches (sample WJB6-4) (Fig. 11). The calculated $\mathrm{Li}_{2} \mathrm{O}$ contents for coal ashes from the WJB-6 Coal range from $0.12 \%$ to $0.34 \%$, with a mean of $0.22 \%$, which is comparable to $\mathrm{Li}_{2} \mathrm{O}$ contents in the Guanbanwusu coal ashes $(0.21 \%$, Dai et al., $2012 \mathrm{~b} ; 0.26 \%$, Sun et al., 2012). Meanwhile, the $\mathrm{Li}_{2} \mathrm{O}$ content is comparable to the industrial grade $(0.2 \%$; DZ/T 0203-2002) for Li-bearing pegmatite deposits in China, except the uppermost coal bench (sample WJB6-1) with $0.12 \% \mathrm{Li}_{2} \mathrm{O}$ (Fig. 11), suggesting a potential coal-hosted Li deposit.

The FHS-23 and FHS-27 Coals have relatively elevated Li concentrations, in the range of 43 to 106 $\mu \mathrm{g} / \mathrm{g}$ (76 $\mu \mathrm{g} / \mathrm{g}$ on average) and of 30 to $62 \mu \mathrm{g} / \mathrm{g}$ (41 $\mu \mathrm{g} / \mathrm{g}$ on average), respectively, compared to the average $\mathrm{Li}$ abundance for world hard coals (14 $\mu \mathrm{g} / \mathrm{g}$, Ketris and Yudovich, 2009). However, due to low ash yield (11.6\% on average), the $\mathrm{Li}_{2} \mathrm{O}$ content for the FHS-23 Coal ash is as high as $1796 \mu \mathrm{g} / \mathrm{g}$.

It is generally accepted that $\mathrm{Li}$ in sedimentary rocks is thought to be hosted by micas (Neiva et al., 1987), kaolinite (Ashrey, 1973), and mica-type clay phases (Middleburg et al., 1988). Li in coal is generally considered to be housed by kaolinite, mica and tourmaline (Seredin et al., 2013), as well as by chlorite (Dai et al., 2012b). The correlation analysis deduces that the highly-elevated Li abundance in the Haerwusu and Guanbanwusu coals in the Jungar Coalfield chiefly occurs in clay minerals (e.g., kaolinite, chlorite and to a lesser extent illite) (Dai et al., 2008b, 2012b). Sun et al. (2012) concluded that kaolinite, boehmite and chlorite-group minerals in the Guanbanwusu coals are the most likely carriers for Li enrichment in the sedimentary stages. Additionally, trace amount of Li is probably organically-associated (Seredin et al., 2013; Swaine, 1990). In the present study, the Li positively correlates with the ash yield ( $\mathrm{r}=0.53), \mathrm{Al}_{2} \mathrm{O}_{3}(\mathrm{r}=0.71)$ 
and kaolinite $(\mathrm{r}=0.75$; Fig. $5 \mathrm{~L})$ and shows a similar vertical distribution to that of kaolinite through the WJB-6 Coal section (Fig. 11), indicating that kaolinite is the most likely carrier for Li enrichment. This is also confirmed by the fact that the coals with relatively high kaolinite contents (e.g., WJB-6 Coal) have the highly-elevated concentrations of $\mathrm{Li}$ while the coals with low or undetected kaolinite contents have lower $\mathrm{Li}$ abundances. Additionally, Li shows a linear correlation with $\mathrm{MgO}(\mathrm{r}=0.75$; Fig. $5 \mathrm{M})$ which is primarily incorporated into chamosite as indicated in Fig. 8B, suggesting a chamosite affinity. However, the chamosite-hosted Li should not be the dominant form due to low chamosite contents in these investigated coals. The modes of Li in coals investigated are as adsorption ions onto kaolinite or chamosite surface or as substitution in the vacant octahedral sites of kaolinite or chamosite (Dai et al., 2012b; Sun et al., 2012).

Previous works documented that the highly-elevated concentration of $\mathrm{Li}$ in the Guanbanwusu (Dai et al., 2012b; Sun et al., 2012) and Haerwusu coals (Dai et al., 2008b) was derived from moyite, bauxite and possibly, to a lesser extent volcanic tuff layers, all of which are located in the sediment-source region and have enriched Li concentrations (e.g., $412 \mu \mathrm{g} / \mathrm{g} \mathrm{Li}$ in bauxite; Sun et al., 2012). However, the Emeishan basalt, serving as source rock for the Late Permian coals (Dai et al., 2005, 2016b), would be expected to contain relatively low $\mathrm{Li}$ content due to low $\mathrm{Li}$ abundance in basic igneous rocks $(13 \mu \mathrm{g} / \mathrm{g}$; Wedepohl, 1995). Meanwhile, Li contents in the Late Permian coals in western Guizhou Province, originated from the Emeishan basalt, are generally below $40 \mu \mathrm{g} / \mathrm{g}$ (Dai et al., 2005; Li et al., 2016; Zhuang et al., 2000). These appear to indicate that terrigenous material input did not account for the enrichment of $\mathrm{Li}$ in the WJB-6 Coal (with low ash yield) and thus an additional source of $\mathrm{Li}$ would be expected. A possible explanation for Li enrichment in the WJB-6 Coal is the supply of Li-rich hydrothermal solutions that penetrate into peat or coal seam during coalification stage. In addition, the UCC-normalized REY patterns of the investigated coals (Fig. 10) also indicate the existence of hydrothermal solution activity. The hydrothermal fluid, causing Li to be enriched in coals investigated, is the most likely ascending (exfiltrational) type rather than descending (infiltrational) type (Seredin and Finkelman, 2008) for the following reasons: (1) the descending solutions derived from leaching of the basaltic composition (Emeishan basalt) cannot provide abundant source of Li, although the high-Ti basalt may provide relatively high Li abundance; (2) unlike the coarse-grain sediments, the mudstone, occurring as the host rocks, cannot serve as channels for migration of the Li-bearing solutions, and thus largely prevents hydrothermal fluid penetrating into the overlying and underlying peat/coal seam.

\subsubsection{Niobium and Tantalum}

The average contents of $\mathrm{Nb}$ and Ta in the FHS-23, FHS-27, WJB-6 and WJB-7 Coals are 23.9 and 2.7 $\mu \mathrm{g} / \mathrm{g}, 33.1$ and $3.4 \mu \mathrm{g} / \mathrm{g}, 15.5$ and $5.4 \mu \mathrm{g} / \mathrm{g}$, and 44.1 and $14.7 \mu \mathrm{g} / \mathrm{g}$, respectively, all of which are strikingly higher than those of world coals $(3.7 \mu \mathrm{g} / \mathrm{g}$ and $0.3 \mu \mathrm{g} / \mathrm{g}$, respectively; Ketris and Yudovich, 2009). According to trace element concentration level of "metalliferous coal" (Seredin and Finkelman, 2008), the investigated coals, with >10 times higher Ta content than the average value for world coals (Ketris and Yudovich, 2009), are classified as metalliferous coals. The calculated $\mathrm{Nb}$ and Ta abundances in coal ash can reach 196.7 and $33.3 \mu \mathrm{g} / \mathrm{g}$, respectively, both of which are comparable to the corresponding $\mathrm{Nb}$ and $\mathrm{Ta}$ abundances in the $\mathrm{Nb}(\mathrm{Ta})-\mathrm{Zr}(\mathrm{Hf})-\mathrm{REE}-\mathrm{Ga}$ polymetallic deposit in the Late Permian Xuanwei Formation of eastern Yunnan, southwestern China (Dai et al., 2010; Zhao et al., 2017).

Niobium and Ta in coals most commonly occur in zircon, anatase and rutile (Dai et al., 2016b; Li et al., 2016). $\mathrm{Nb}$ and $\mathrm{Ta}$ in coals investigated show significantly positive correlations with $\mathrm{Al}$ ( $\mathrm{r}=0.77$ and 0.82 , respectively), $\mathrm{K}$ ( $\mathrm{r}=0.96$ and 0.91 , respectively) and $\mathrm{Ti}(\mathrm{r}=0.82$ and 0.83 , respectively), indicating that $\mathrm{K}-$ and Ti-bearing mineral phases (e.g., rectorite, anatase) are important in hosting the highly-elevated concentrations of $\mathrm{Nb}$ and $\mathrm{Ta}$ as indicated by linear correlations of $\mathrm{Nb}$-anatase $(\mathrm{r}=0.85$; Fig. $5 \mathrm{~N})$, 
Nb-rectorite $(\mathrm{r}=0.64)$, Ta-anatase $(\mathrm{r}=0.76)$ and Ta-rectorite $(\mathrm{r}=0.52)$. Meanwhile, $\mathrm{Nb}$ and $\mathrm{Ta}$ display significant correlation ( $\mathrm{r}=0.92$ ), suggesting a similar geochemical behavior. The $\mathrm{Nb} / \mathrm{Ta}$ ratios in the coals range from 1.9 to 15.0, with the average of 7.5, higher than that for zircon (3.0; Belousova et al., 2002). This suggests that zircon control on $\mathrm{Nb}$ and Ta enrichment is subordinate, although significant correlation exists between $\mathrm{Nb}$ and $\mathrm{Zr}(\mathrm{r}=0.91$; Fig. 5O) as well as $\mathrm{Ta}$ and $\mathrm{Zr}(\mathrm{r}=0.75)$.

The elevated $\mathrm{Nb}$ and Ta abundances in the Late Permian coals and its associated rocks in southwestern China have been investigated and been attributed to the derivation from terrigenous material input ( $\mathrm{Li}$ et al., 2016; Zhuang et al., 2012), alkaline tuff or hydrothermal fluid (Dai et al., 2016b; Zhao et al., 2016a, 2016b, 2017). Terrigenous material input is the main source for mineral and trace element in coal and determines the background contents of trace elements (Finkelman, 1993), but, the highly-elevated abundances of trace elements in coals can seldom be caused by this way (Seredin and Finkelman, 2008), with a few exceptions of the enrichment of Al and Ga in the Jungar Coalfield as reported by Dai et al. (2006, 2008b, 2012b), as well as elevated-concentrations of rare earth elements reported by Seredin and Dai (2012) and Dai et al. (2016c). The low-Ti and high-Ti basalts, serving as the source rocks, contain $14.7 \mu \mathrm{g} / \mathrm{g} \mathrm{Nb}$ and $0.85 \mu \mathrm{g} / \mathrm{g}$ Ta as well as $31.4 \mu \mathrm{g} / \mathrm{g} \mathrm{Nb}$ and $1.9 \mu \mathrm{g} / \mathrm{g} \mathrm{Ta}$, respectively (Xu et al., 2001), which are extraordinarily lower than the corresponding $\mathrm{Nb}(196.7 \mu \mathrm{g} / \mathrm{g})$ and $\mathrm{Ta}(33.3 \mu \mathrm{g} / \mathrm{g})$ abundances in the investigated coal ashes. This appears to indicate that terrigenous material input cannot account for the highly-elevated concentrations of $\mathrm{Nb}$ and $\mathrm{Ta}$, and thus there must have been additional contributions for $\mathrm{Nb}$ and Ta enrichment. Additionally, the large-scale anatase deposit, distributed within the area of Qinglong County, western Guizhou Province and developed on the paleokarst surface at the top of the Maokou Formation (Zhang et al., 2014), may act as another source of $\mathrm{Nb}$ and Ta. However, the authigenic anatase contains low $\mathrm{Nb}$ and Ta contents as reported by Zhang et al. (2014). The highly-elevated concentrations of $\mathrm{Nb}$-Ta-REY-Ga were also found in the alkaline volcanic ash within the Late Permian coal-bearing strata (Dai et al., 2010; Zhao et al., 2017) and alkaline syenitic dikes intruding the Emeishan basalt (Wang et al., 2015), both of which may serve as source rocks for the Late Permian coal-bearing strata. If the alkaline volcanic ash or dike serves as terrigenous source rocks for the coals investigated, the investigated coals would be expected to have highly-elevated concentrations of Nb-Ta-REY-Ga and to show significantly negative Eu anomalies (Zhao et al., 2017; Wang et al., 2015). However, the coals are characterized by comparable $\mathrm{Nb}$ and Ta but depleted REY and Ga contents relative to alkaline volcanic ash or dike, as well as by positive Eu anomalies, indicating that the alkaline volcanic ash or dike plays a subordinate role in $\mathrm{Nb}$ and Ta enrichment. However, it is noted that the highly-elevated concentrations of Nb-Ta-REE-Zr-Ga in alkaline syenitic dikes (Wang et al., 2015) may have derived from highly evolved, fluid-rich magma in magmatic-hydrothermal stage (Wang et al., 2015). The highly-elevated concentrations of $\mathrm{Nb}$ and $\mathrm{Ta}$ in the investigated coals may have formed from ascending hydrothermal fluid which penetrates along faults in the base rocks into coal basin as reported by Seredin and Finkelman (2008). This is in accordance with the previous study by Dai et al. (2017), who concluded that the anomalous concentrations of $\mathrm{Nb}$ and $\mathrm{Ta}$ in the Moxinpo coals in the southwestern China are resulted from the influx of ascending hydrothermal solution during early-diagenetic stage.

\section{Conclusions}

The Late Permian coals in the Zhina Coalfield, Guizhou Province, southwest China, reach the semianthracite-anthracite coal rank and have super-low to low ash yields. The sulfur contents vary considerably through coal sections and are mostly in the range of medium-high sulfur coals, indicating a varying degree of seawater influence. The mineral assemblage of the FHS-23 and FHS-27 Coals is mainly dominated by the occurrence of pyrite and rectorite, along with lesser but varying proportions of quartz. 
The mineral matter of the WJB-6 Coal consists mainly of kaolinite and rectorite, and to a lesser extent pyrite, with lesser but varying amounts of quartz while that of the WJB-7 Coal chiefly consists of quartz and rectorite, along with varying proportions of pyrite. A high authigenic quartz content, rather than detrital input of terrigenous origin, was evidenced for some samples. In comparison with world hard coals, the enriched trace elements include $\mathrm{Li}, \mathrm{Nb}$ and Ta in the WJB-6 Coal, Nb and Ta in the WJB-7 Coal, Li, V, Zr, $\mathrm{Nb}$, Mo and Ta in the FHS-23 Coal and Li, V, Zr, Nb, Mo, Ta and U in the FHS-27 Coal. The carbonaceous mudstone from the WJB-7 Coal contains higher some trace elements concentrations than those of other coals due to more input of terrigenous material. Kaolinite, and to a lesser extent chamosite, are the most likely carriers for the highly-elevated Li abundances in the WJB-6 Coal. Rectorite and anatase are important in hosting the highly-elevated abundances of $\mathrm{Nb}$ and $\mathrm{Ta}$ in the investigated coals.

The Emeishan basalt serves as the dominant source rocks for the Late Permian coals investigated in western Guizhou Province, China, although in some cases, other rocks (e.g., felsic-intermediate igneous rocks or volcanic ash) occur as source rocks and cause the geochemical anomalies of local horizons or regions. The WJB-6, WJB-7, FHS-23 and FHS-27 Coals are formed in an iron-rich and sulfur-rich marine-influenced environment, but the latter three Coals are subjected to a more enhanced marine influence than the former WJB-6 Coal. This resulted in higher concentrations of S-As-Mo-U-Hg in the WJB-7, FHS-23 and FHS-27 Coals. The higher concentrations of S-Fe-As-Mo-U-Hg in the high-sulfur coals relative to the medium-sulfur and low-sulfur coals suggest that the degree of marine influence, together with terrigenous material input, played a pivotal role for their enrichments. Ascending hydrothermal solution, rather than detrital material input of terrigenous origin, caused probably the geochemical anomalies of $\mathrm{Nb}$ and Ta in coals as well as of Li in the WJB-6 Coal, although the high-Ti basalt can provide relatively high background trace elements contents.

\section{Acknowledgments}

This research was funded by the National Key Basic Research Program of China (no. 2014CB238901), the National Natural Science Foundation of China (nos. 41372166 and 41402141), and the National Science Foundation for Young Scientists of China (no. 41602176). The authors would like to express sincere thanks to the Energy Bureau of Guizhou Province for assistance with sampling and acknowledge Institute of Environmental Assessment and Water Research, CSIC, Spain for assistance with the sample analysis. The authors also greatly thank Prof. Shifeng Dai of China University of Mining and Technology (Beijing) for his assistance and advice during SEM-EDX analysis.

\section{References}

Ashey, M. M., 1973. Occurrence of Li, B, Cu and Zn in some Egyptian Nile sediments. Geochim. Cosmochim. Acta. 37 , 2449-2458.

ASTM Standard D3173-11, 2011. Test Method for Moisture in the Analysis Sample of Coal and Coke. ASTM International, West Conshohocken, PA.

ASTM Standard D3174-11, 2011. Annual Book of ASTM Standards. Test Method for Ash in the Analysis Sample of Coal and Coke. ASTM International, West Conshohocken, PA.

ASTM Standard D3175-11, 2011. Test Method for Volatile Matter in the Analysis Sample of Coal and Coke. ASTM International, West Conshohocken, PA.

ASTM Standard D388-12, 2012. Standard Classification of Coals by Rank. ASTM International, West Conshohocken, PA (Reapproved 2007).

Blissett, R.S., Smalley, N., Rowson, N.A., 2014. An investigation into six coal fly ashes from the United Kingdom and Poland to evaluate rare earth element content. Fuel 119, 236-239.

Burger, K., Zhou, Y., Tang, D., 1990. Synsedimentary volcanic-ash-derived illite tonsteins in Late Permian coal-bearing 
formations of southwestern China. Int. J. Coal Geol. 15, 341-356.

Belousova, E.A., Griffin, W.L., O’Reilly, S.Y., Fisher, N.I., 2002. Igneous zircon trace element composition as an indicator of source rock type. Contrib. Mineral. Petrol. 143, 602-622.

Casagrande DJ, 1987. Sulphur in peat and coal. In: Scott AC (ed), Coal and coal-bearing strata: recent advances. Geol. Soc. Lond. Spec. Publ. 32, pp. 87-105.

China Coal Geology Bureau, 1996. Sedimentary Environments and Coal Accumulation of Late Permian Coal Formation in Western Guizhou, Southern Sichuan, and Eastern Yunnan, China. Chongqing University Press, Chongqing, pp. 156-216 (in Chinese with English abstract).

Chou, C.-L., 1990. Geochemistry of sulfur in coal. In: Orr, W.L., White, C.M. (Eds.), Geochemistry of Sulfur in Fossil Fuels. Am. Chem. Soc. Symp. Ser. 429, 30-52.

Chou, C.-L., 2012. Sulfur in coals: a review of geochemistry and origins. Int. J. Coal Geol. 100, 1-13.

Chung, F.H., 1974. Quantitative interpretation of X-ray diffraction patterns of mixtures: I. Matrix flushing method for quantitative multicomponent analysis. J. Appl. Crystalogr. 7, 519-525.

Crowley, S.S., Stanton, R.W., Ryer, T.A., 1989. The effects of volcanic ash on the maceral and chemical composition of the C coal bed, Emery Coal Field, Utah. Org. Geochem. 14, 315-331.

Dai, S., Ren, D., Hou, X., Shao, L., 2003. Geochemical and mineralogical anomalies of the late Permian coal in the Zhijin Coalfield of Southwest China and their volcanic origin. Int. J. Coal Geol. 55, 117- 138.

Dai, S., Li, D., Ren, D., Tang, Y., Shao, L., Shi, Z., 2004. Geochemistry of the late Permian No. 30 Coal Seam, Zhijin Coalfield of Southwest China: influence of the siliceous low-temperature hydrothermal fluid. Appl Geochem. 19, $1315-1330$

Dai, S., Ren, D., Tang, Y., Yue, M., Hao, L., 2005. Concentration and distribution of elements in Late Permian coals from western Guizhou Province, China. Int. J. Coal Geol. 61, 119-137.

Dai, S., Ren, D., Li, S., 2006. Discovery of the superlarge gallium ore deposit in Jungar, Inner Mongolia, north China. Chin. Sci. Bull. 51, 2243-2252.

Dai, S., Zhou, Y., Ren, D., Wang, X., Li, D., Zhao, L., 2007a. Geochemistry and mineralogy of the Late Permian coals from the Songzao Coalfield, Chongqing, southwestern China. Sci. China. Ser. D Earth Sci. 50, 678-688.

Dai, S., Chou, C. L., 2007b. Occurrence and origin of minerals in a chamosite-bearing coal of Late Permian age, Zhaotong, Yunnan, China. Am. Mineral. 92, 1253-1261.

Dai, S., Ren, D., Zhou, Y., Chou, C.-L., Wang, X., Zhao, L., Zhu, X., 2008a. Mineralogy and geochemistry of a superhigh-organic-sulfur coal, Yanshan Coalfield, Yunnan, China: evidence for a volcanic ash component and influence by submarine exhalation. Chem. Geol. 255, 182-194.

Dai, S., Li, D., Chou, C.-L., Zhao, L., Zhang, Y., Ren, D., Ma, Y., Sun, Y., 2008b. Mineralogy and geochemistry of boehmite-rich coals: new insights from the Haerwusu Surface Mine, Jungar Coalfield, Inner Mongolia, China. Int. J. Coal Geol. 74, 185-202.

Dai, S., Tian, L., Chou, C.-L., Zhou, Y., Zhang, M., Zhao, L., Wang, J., Yang, Z., Cao, H., Ren, D., 2008c. Mineralogical and compositional characteristics of Late Permian coals from an area of high lung cancer rate in XuanWei, Yunnan, China: Occurrence and origin of quartz and chamosite. Int. J. Coal Geol. 76, 318-327.

Dai, S., Zhou, Y., Zhang, M., Wang, X., Wang, J., Song, X., Jiang, Y., Luo, Y., Song, Z., Yang, Z., Ren, D., 2010. A new type of $\mathrm{Nb}(\mathrm{Ta})-\mathrm{Zr}(\mathrm{Hf})-\mathrm{REE}-\mathrm{Ga}$ polymetallic deposit in the late Permian coal-bearing strata, eastern Yunnan, southwestern China: possible economic significance and genetic implications. Int. J. Coal Geol. 83, 55-63.

Dai, S., Wang, X., Zhou, Y., Hower, J.C., Li, D., Chen, W., Zhu, X., 2011. Chemical and mineralogical compositions of silicic, mafic, and alkali tonsteins in the late Permian coals from the Songzao Coalfield, Chongqing. Southwest China. Chem. Geol. 282, 29-44.

Dai, S., Ren, D., Chou, C.-L., Finkelman, R.B., Seredin, V.V., Zhou, Y., 2012a. Geochemistry of trace elements in Chinese 
coals: a review of abundances, genetic types, impacts on human health, and industrial utilization. Int. J. Coal Geol. 94 , $3-21$.

Dai, S., Jiang, Y., Ward, C.R., Gu, L., Seredin, V.V., Liu, H., Zhou, D., Wang, X., Sun, Y., Zou, J., Ren, D., 2012 b. Mineralogical and geochemical compositions of the coal in the Guanbanwusu Mine, Inner Mongolia, China: further evidence for the existence of an $\mathrm{Al}$ (Ga and REE) ore deposit in the Jungar Coalfield. Int. J. Coal Geol. 98, 10-40.

Dai, S., Zhang,W., Seredin, V.V.,Ward, C.R., Hower, J.C., Song, W.,Wang, X., Li, X., Zhao, L., Kang, H., Zheng, L., Wang, P., Zhou, D., 2013. Factors controlling geochemical and mineralogical compositions of coals preserved within marine carbonate successions: a case study from the Heshan Coalfield, southern China. Int. J. Coal Geol. 110, 77-100.

Dai, S., Li, T., Seredin, V.V., Ward, C.R., Hower, J.C., Zhou, Y., Zhang, M., Song, X., Song, W., 2014a. Origin of minerals and elements in the Late Permian coals, tonsteins, and host rocks of the Xinde Mine, Xuanwei, eastern Yunnan, China. Int. J. Coal Geol. 121, 53-78.

Dai, S., Luo, Y., Seredin, V.V., Ward, C.R., Hower, J.C., Zhao, L., Liu, S., Zhao, C., Tian, H., Zou, J., 2014b. Revisiting the late Permian coal from the Huayingshan, Sichuan, southwestern China: Enrichment and occurrence modes of minerals and trace elements. Int. J. Coal Geol. 122, 110-128.

Dai, S., Seredin, V.V., Ward, C.R., Hower, J.C., Xing, Y., Zhang,W., Song,W., Wang, P., 2015a. Enrichment of $\mathrm{U}-\mathrm{Se}-\mathrm{Mo}-\mathrm{Re}-\mathrm{V}$ in coals preserved within marine carbonate successions: geochemical and mineralogical data from the Late Permian Guiding Coalfield, Guizhou, China. Mineralium Deposita 50, 159-186.

Dai, S., Yang, J., Ward, C.R., Hower, J.C., Liu, H., Garrison, T.M., French, D., O'Keefe, J.M.K., 2015b. Geochemical and mineralogical evidence for a coal-hosted uranium deposit in the Yili Basin, Xinjiang, northwestern China. Ore Geol. Rev. $70,1-30$.

Dai, S., Yan, X., Ward, C.R., Hower, J.C., Zhao, L., Wang, X., Zhao, L., Ren, D., Finkelman, R.B., 2016a. Valuable elements in Chinese coals: a review. Int. Geol. Rev. http://dx.doi.org/10.1080/00206814.2016.1197802.

Dai, S., Liu, J., Ward, C.R., Hower, J.C., French, D., Jia, S., Hood, M.M., and Garrison, T.M., 2016b, Mineralogical and geochemical compositions of Late Permian coals and host rocks from the Guxu Coalfield, Sichuan Province, China, with emphasis on enrichment of rare metals. Int. J. Coal Geol. 166, 71-95.

Dai, S., Chekryzhov, I.Y., Seredin, V.V., Nechaev, V.P., Graham, I.T., Hower, J.C., Ward, C.R., Ren, D., Wang, X., $2016 c$. Metalliferous coal deposits in East Asia (Primorye of Russia and South China): a review of geodynamic controls and styles of mineralization. Gondwana Res. 29, 60-82.

Dai, S., Graham, I.T., Ward, C.R., 2016d. A review of anomalous rare earth elements and yttrium in coal. Int. J. Coal Geol. $159,82-95$.

Dai, S., Xie, P., Jia, S., Ward, C. R., Hower, J. C., Yan, X., French, D., 2017. Enrichment of U-Re-V-Cr-Se and rare earth elements in the Late Permian coals of the Moxinpo Coalfield, Chongqing, China: Genetic implications from geochemical and mineralogical data. Ore Geol. Rev. 80, 1-17.

Damberger, H.H., Harvey, R.D., Ruch, R.R., Thomas Jr., J., 1984. Coal characterization. In: Cooper, B.R., Ellingson, W.A. (Eds.), The Science and Technology of Coal and Coal Utilization. Plenum Press, pp. 7-45 (Chap. 2).

Degens, E., Williams, E., Keith, M., 1957. Environmental studies of carboniferous sediments part I: Geochemical criteria for different marine from freshwater shales. AAPG. 41, 2427-2455.

Diehl, S.F., Goldhaber, M.B., Hatch, J.R., 2004. Modes of occurrence of mercury and trace elements in coals from the warrior field, Black Warrior Basin, Northwestern, Alabama. Int. J. Coal Geol. 59, 193-208.

Diehl, S. F., Goldhaber, M. B., Koenig, A. E., Lowers, H. A., Ruppert, L. F., 2012. Distribution of arsenic, selenium, and other trace elements in high pyrite Appalachian coals: evidence for multiple episodes of pyrite formation. Int. J. Coal Geol. 94, 238-249.

DZ/T 0203-2002, 2003. Geology and Ore Deposit Standard Specifications for Rare Metal Mineral Exploration of the People's Republic of China. Geological Publishing, Beijing. Pp. 40. ISBN 978-7-116-03802-8 (in Chinese). 
Finkelman, R.B., 1993. Trace and minor elements in coal. In: Engel, M.H., Macko, S. (Eds.), Organic Geochemistry. Plenum, New York, pp. 593-607.

Finkelman, R.B., 1994. Modes of occurrence of potentially hazardous trace elements in coal: levels of confidence. Fuel Process. Technol. 39, 21-34.

GB/T 15224.1-2010 (National Standard of P.R. China), 2010. Classification for Quality of Coal. Part 1: Ash Yield (in Chinese).

He, B., Xu, Y.G., Chung, S.L., Wang, Y.M., Luo, Z.Y., 2006. Sedimentation and lithofacies paleogeography in southwestern China before and after the Emeishan flood volcanism: New insights into surface response to mantle plume activity. J. Geol. 114, 117-132

Hower, J.C., Ruppert, L.F., Eble, C.F., 1999. Lanthanide, yttrium, and zirconiumanomalies in the Fire Clay coal bed, Eastern Kentucky. Int. J. Coal Geol. 39, 141-153.

Hower, J.C., Groppo, J.G., Henke, K.R., Hood, M.M., Eble, C.F., Honaker, R.Q., Zhang, W., Qian, D., 2015a. Notes on the potential for the concentration of rare earth elements and yttrium in coal combustion fly ash. Minerals 5, 356-366.

Hower, J.C., Eble, C.F., O'Keefe, J.M.K., Dai, S.,Wang, P., Xie, P., Liu, J.,Ward, C.R., French, D., 2015b. Petrology, palynology, and geochemistry of Gray Hawk Coal (Early Pennsylvanian, Langsettian) in Eastern Kentucky, USA. Minerals 5, 592-622.

Hower, J.C., Dai, S., 2016. Petrology and Chemistry of sized Pennsylvania anthracite, with emphasis on the distribution of Rare Earth Elements. Fuel 185, 305-315.

Hower, J.C., Eble, C.F., Dai, S. Belkin, H.E., 2016. Distribution of rare earth elements in eastern Kentucky coals: Indicators of multiple modes of enrichment. Int. J. Coal Geol. 160-161, 73-81.

Isozaki, Y., Yao, J.X., Matsuda, T., Sakai, H., Ji, Z.S., Shimizu, N., Kobayashi, N., Kawahata, H, Nishi, H., Takano, M., and Kubo, T., 2004. Stratigraphy of the Middle-Upper Permian and Lower Triassic at Chaotian, Sichuan, China. Proc. Jpn. Acad., Ser. B Phys. Biol. Sci. 80, 10-16.

Ketris, M.P., Yudovich, Ya. E., 2009. Estimations of Clarkes for carbonaceous biolithes: world average for trace element contents in black shales and coals. Int. J. Coal Geol. 78, 135-148.

Kolker, A., 2012. Minor element distribution in iron disulfides in coal: A geochemical review. Int. J. Coal Geol. 94, 32-43.

Li, B., Zhuang, X., Li, J., Querol, X., Font, O., Moreno, N., 2016. Geological controls on mineralogy and geochemistry of the Late Permian coals in the Liulong Mine of the Liuzhi Coalfield, Guizhou Province, Southwest China. Int. J. Coal Geol. $154,1-15$.

Liu, J., Yang, Z., Yan, X., Ji, D., Yang, Y., Hu, L., 2015. Modes of occurrence of highly-elevated trace elements in superhigh-organic-sulfur coals. Fuel 156, 190-197.

Luther III, G.W., 1991. Pyrite synthesis via polysulfide compounds. Geochim. Cosmochim. Acta. 55, 2839-2849.

Mayfield, D.B., Lewis, A.S., 2013. Environmental Review of Coal Ash as a Resource for Rare Earth and Strategic Elements. Paper Presented at the World of Coal Ash Conference, Lexington, KY, April 22-25.

Middelburg, J. J., van der Weijden, C. H., Woittiez, J. R., 1988. Chemical processes affecting the mobility of major, minor and trace elements during weathering of granitic rocks. Chem. Geol. 68, 253-273.

Murali, A.V., Parthasarathy, R., Mahadevan, T.M., Sankar Das, M., 1983. Trace element characteristics, REE patterns and partition coefficients of zircons from different geological environments-a case study on Indian zircons. Geochim. Cosmochim. Acta. 47, 2047-2052.

Neiva, A. M., Neiva, J. M., Parry, S. J., 1987. Geochemistry of the granitic rocks and their minerals from Serra da Estrela, Central Portugal. Geochim. Cosmochim. Acta. 51, 439-454.

Permana, A.K., 2011. Mineralogical Variation and Changes in the South Walker Creek Coals, Bowen Basin, Queensland, Australia. MSc thesis (unpublished), University of New South Wales, Australia, (276 pp.).

Permana, A. K., Ward, C. R., Li, Z., Gurba, L. W., 2013. Distribution and origin of minerals in high-rank coals of the South 
Walker Creek area, Bowen Basin, Australia. Int. J. Coal Geol. 116, 185-207.

Querol, X., Whateley, M.K.G., Fernandez-Turiel, J.L., Tuncali, E., 1997. Geological controls on the mineralogy and geochemistry of the Beypazari lignite, Central Anatolia, Turkey. Int. J. Coal Geol. 33, 255-271.

Rao, C.P., Gluskoter, H.J., 1973. Occurrence and Distribution of Minerals in Illinois Coals. Illinois State Geological Survey Circular 476 (56 pp.).

Rao, P. D., Walsh, D. E., 1999. Influence of environments of coal deposition on phosphorous accumulation in a high latitude, northern Alaska, coal seam. Int. J. Coal Geol. 38, 261-284.

Ren, D.Y., 1996. Mineral matters in coal. In: Han, D.X. (Ed.), Coal Petrology of China. Publishing House of China University of Mining and Technology, Xuzhou, pp. 67-77 (in Chinese with English abstract).

Rozelle, P.L., Khadilkar, A.B., Pulati, N., Soundarrajan, N., Klima, M.S., Mosser, M.M., Miller, C.E., and Pisupati, S.V., 2016, A study on removal of rare earth elements from U.S. coal byproducts by ion exchange. Metall. Mater. Trans. E. 3, $6-17$.

Sanguesa, F.J., Arostegui, J., Suarez Ruiz, I., 2000. Distribution and origin of clay minerals in the Lower Cretaceous of the Alava Block (Basque-Cantabrian Basin, Spain). Clay Minerals 35: 393-410.

Seredin, V., Finkelman, R.B., 2008. Metalliferous coals: a review of the main genetic and geochemical types. Int. J. Coal Geol. 76, 253-289.

Seredin, V.V., Dai, S., 2012. Coal deposits as a potential alternative source for lanthanides and yttrium. Int. J. Coal Geol. 94 , 67-93.

Seredin, V.V., Dai, S., Sun, Y., Chekryzhov, I.Yu., 2013. Coal deposits as promising sources of rare metals for alternative power and energy-efficient technologies. Appl. Geochem. 31, 1-11.

Shao, L., Jones, T., Gayer, R., Dai, S., Li, S., Jiang, Y., Zhang, P., 2003. Petrology and geochemistry of the high-sulphur coals from the Upper Permian carbonate coal measures in the Heshan Coalfield, southern China. Int. J. Coal Geol. 55, 1-26.

Shao, L., Gao, C., Zhang, C.,Wang, H., Guo, L., Gao, C., 2013. Sequence-paleogeography and coal accumulation of late Permian in Southwestern China. Acta Sedimentol. Sin. 31, 856-864 (in Chinese with English abstract).

Sun, Y.Z., Li, Y.H., Zhao, C.L., Lin, M.Y., Wang, J.X., Qin, S.J., 2010. Concentrations of lithium in Chinese coals. Energy Explor. Exploit. 28, 97-104.

Sun, Y., Zhao, C., Li, Y., Wang, J., Liu, S., 2012. Li distribution and mode of occurrences in Li-bearing coal seam \# 6 from the Guanbanwusu mine, Inner Mongolia, northern China. Energy Explor. Exploit. 30, 109-130.

Susilawati, R., and Ward, C.R., 2006. Metamorphism of mineral matter in coal from the Bukit Asam deposit, south Sumatra, Indonesia. Int. J. Coal Geol. 68, 171-195.

Swaine, D.J., 1990. Trace Elements in Coal. Butterworths, London (278 pp.).

Swaine, D. J., Goodarzi, F., 1995. Environmental Aspects of Trace Elements in Coal. Kluwer Academic Publishers, the Netherlands (312 pp).

Taylor, S.R., McLennan, S.M., 1985. The Continental Crust: Its Composition and Evolution. Blackwell, Oxford (312 pp.).

Vassilev, S.V. and Vassileva, C.G., 1996. Occurrence, abundance and origin of minerals in coals and coal ashes. Fuel Process. Technol. 48, 85-106.

Wang, X., Dai, S., Chou, C.-L., Zhang, M., Wang, J., Song, X., Wang, W., Jiang, Y., Zhou, Y., Ren, D., 2012. Mineralogy and geochemistry of Late Permian coals from the Taoshuping Mine, Yunnan Province, China: evidences for the sources ofminerals. Int. J. Coal Geol. 96-97, 49-59.

Wang, X., Zhang, M., Zhang, W., Wang, J., Zhou, Y., Song, X., Li, T., Li, X., Liu, H., Zhao, L.,2013. Occurrence and origins of minerals in mixed-layer illite/smectite-rich coals of the Late Permian age from the Changxing Mine, eastern Yunnan, China. Int. J. Coal Geol. 102, 26-34.

Wang, F. L., Wang, C. Y., Zhao, T. P., 2015. Boron isotopic constraints on the Nb and Ta mineralization of the syenitic dikes in the 260Ma Emeishan large igneous province (SW China). Ore Geol. Rev. 65, 1110-1126. 
Ward, C.R., 2002. Analysis and significance of mineral matter in coal seams. Int. J. Coal Geol. 50, 135-168.

Ward, C. R., 2016. Analysis, origin and significance of mineral matter in coal: An updated review. Int. J. Coal Geol. 165, $1-27$.

Wedepohl, K. H., 1995. The composition of the continental crust. Geochim. Cosmochim. Acta. 59, 1217-1232.

Whateley, M. K. G., Tuncali, E., 1995. Quality variations in the high-sulphur lignite of the Neogene Beypazari Basin, Central Anatolia, Turkey. Int. J. Coal Geol. 27, 131-151.

Xiao, L., Xu, Y.G., Mei, H.J., Zheng, Y.F., He, B., Pirajno, F., 2004. Distinct mantle sources of low-Ti and high-Ti basalts from the western Emeishan large igneous province, SW China: implications for plume-lithosphere interaction. Earth Planet. Sci. Lett. 228, 525-546.

Xu, Y.G., Chung, S.L., Jahn, B.M.,Wu, G.Y., 2001. Petrologic and geochemical constraints on the petrogenesis of Permian Triassic Emeishan flood basalts in southwestern China. Lithos 58, 145-168.

Xu, S., He, M., 2003. Coal Geology of Guizhou Province. China University of Mining andTechnology Press, Xuzhou (283 pp. (in Chinese with English abstract)).

Zeng, R., Zhuang, X., Koukouzas, N., Xu, W., 2005. Characterization of trace elements in sulphur-rich Late Permian coals in the Heshan coal field, Guangxi, South China. Int. J. Coal Geol. 61, 87-95.

Zhang, M., Nie, A., Xie, F., Zhang, Z., 2014. Study on the geological conditions of metallogenesis of the Shazi large-scale anatase deposit in Qinglong County, Guizhou Province. Chin J. Geochem. 33, 450-458.

Zhao, L., Dai, S., Graham, I., Wang, P., 2016a. Clay mineralogy of coal-hosted Nb-Zr-REE-Ga mineralized beds from Late Permian strata, eastern Yunnan, SW China: Implications for palaeotemperature and origin of the micro-quartz. Minerals 6, 45; doi:10.3390/min6020045.

Zhao, L., Dai, S., Graham, I.T., Li, X., Zhang, B., 2016b. New insights into the lowest Xuanwei Formation in eastern Yunnan Province, SW China: Implications for Emeishan large igneous province felsic tuff deposition and the cause of the end-Guadalupian mass extinction. Lithos 264, 375-391.

Zhao, L., Dai, S., Graham, I.T., Li, X., Liu, H., Song, X., Hower, J.C., Zhou, Y., 2017. Cryptic sediment-hosted critical element mineralization from eastern Yunnan Province, southwestern China: mineralogy, geochemistry, relationship to Emeishan alkaline magmatism and possible origin. Ore Geol. Rev. 80, 116-140.

Zhou, Y., Bohor, B.F., Ren, Y., 2000. Trace element geochemistry of altered volcanic ash layers (Tonsteins) in Late Permian coalbearing formations of eastern Yunnan and western Guizhou Provinces, China. Int. J. Coal Geol. 44, 305-324.

Zhou, M.F., Arndtb, N.T., Malpas, J., Wang, C.Y., Kennedy, A.K., 2008. Two magma series and associated ore deposit types in the Permian Emeishan large igneous province, SW China. Lithos 103, 352-368.

Zhuang, X., Querol, X., Zeng, R., Xu, W., Alastuey, A., López-Soler, A., Plana, F., 2000. Mineralogy and geochemistry of coal from the Liupanshui mining district, Guizhou, south China. Int. J. Coal Geol. 45, 21-37.

Zhuang, X., Su, S., Xiao, M., Li, J., Alastuey, A., Querol, X., 2012. Mineralogy and geochemistry of the Late Permian coals in the Huayingshan coal-bearing area, Sichuan Province, China. Int. J. Coal Geol. 94, 271-282. 


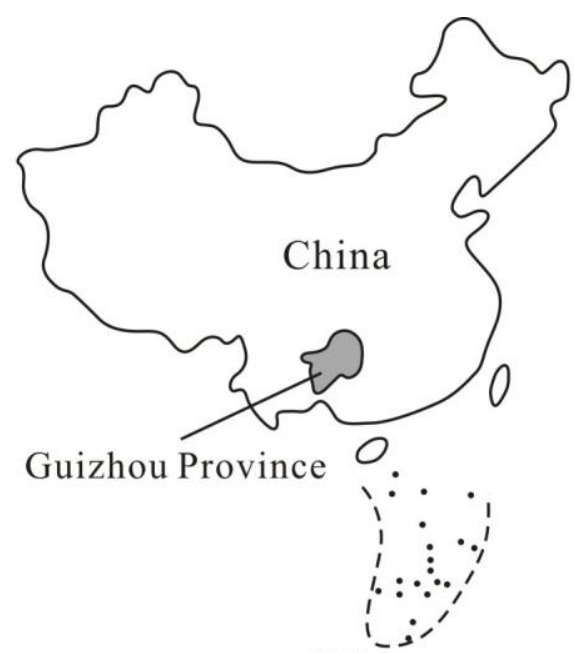

(A)

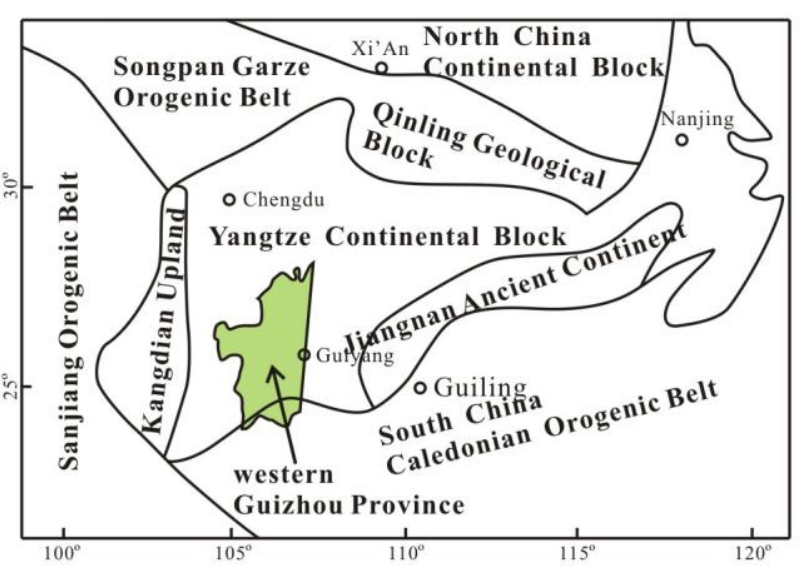

(B)

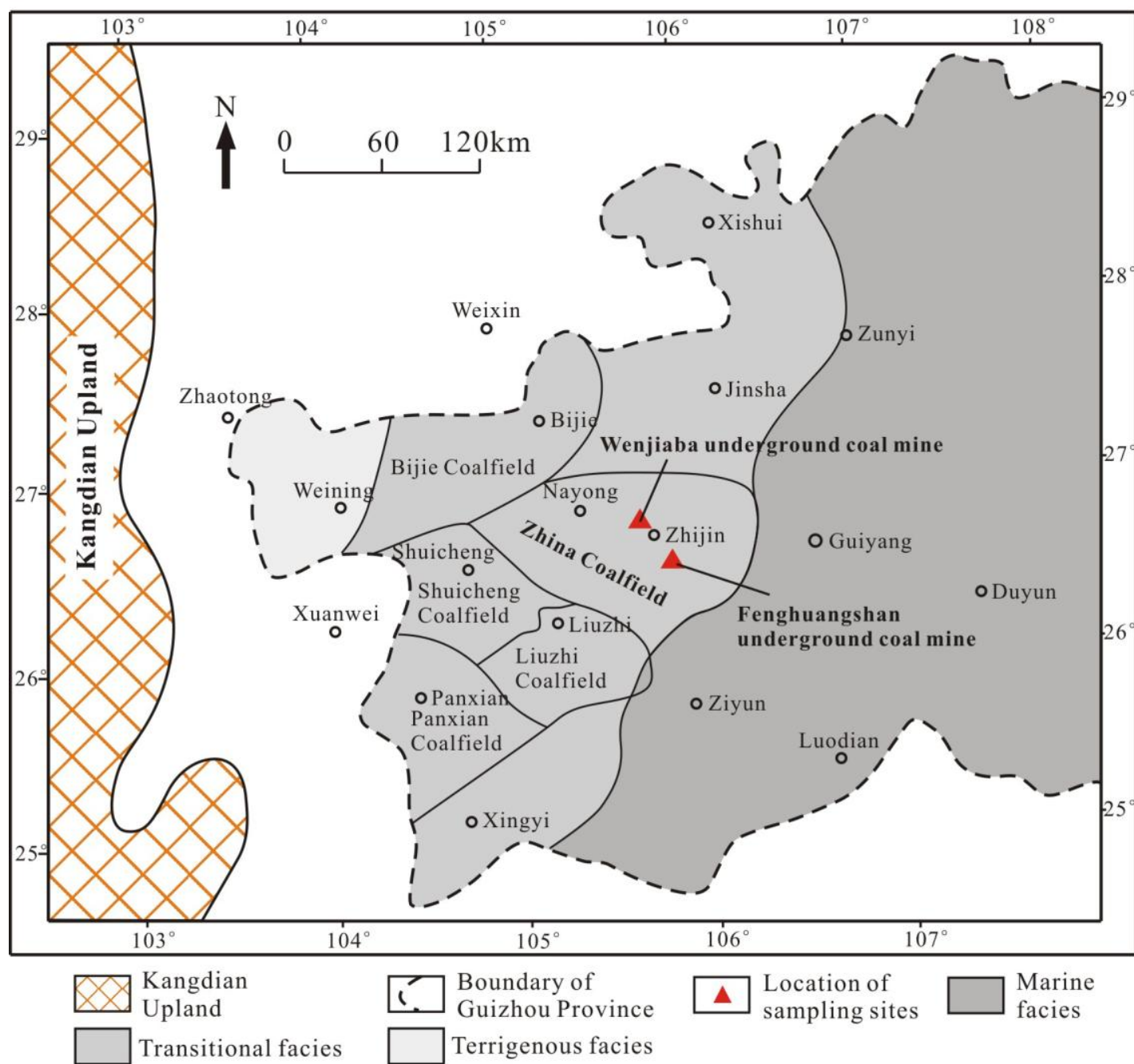

( C )

Fig. 1 Geological location of Guizhou Province (A), western Guizhou Province (B) and sampling sites (C) within the studied 


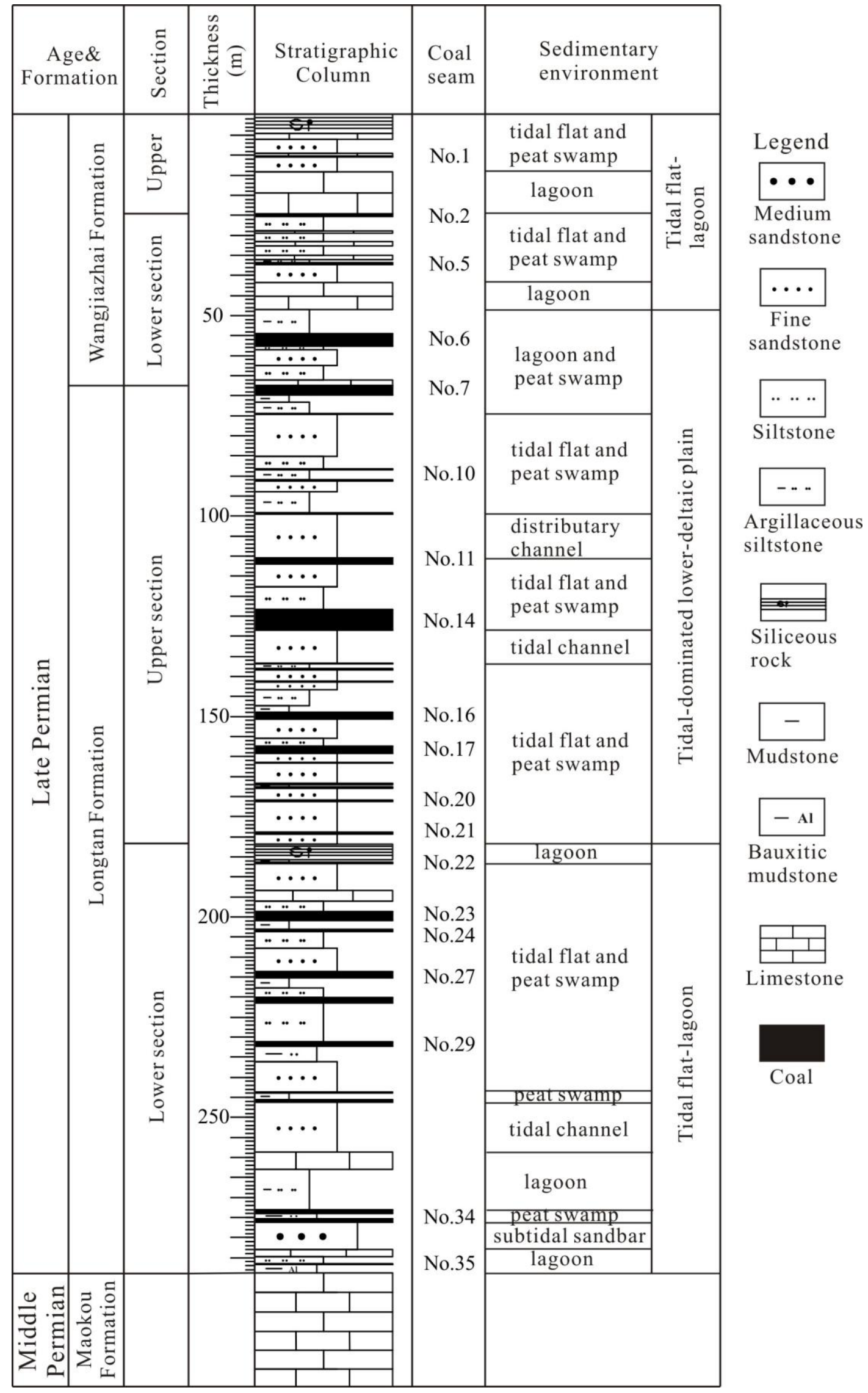

Fig. 2 Sedimentary sequence in the Zhina Coalfield (Based on data from Xu and He (2003)) 

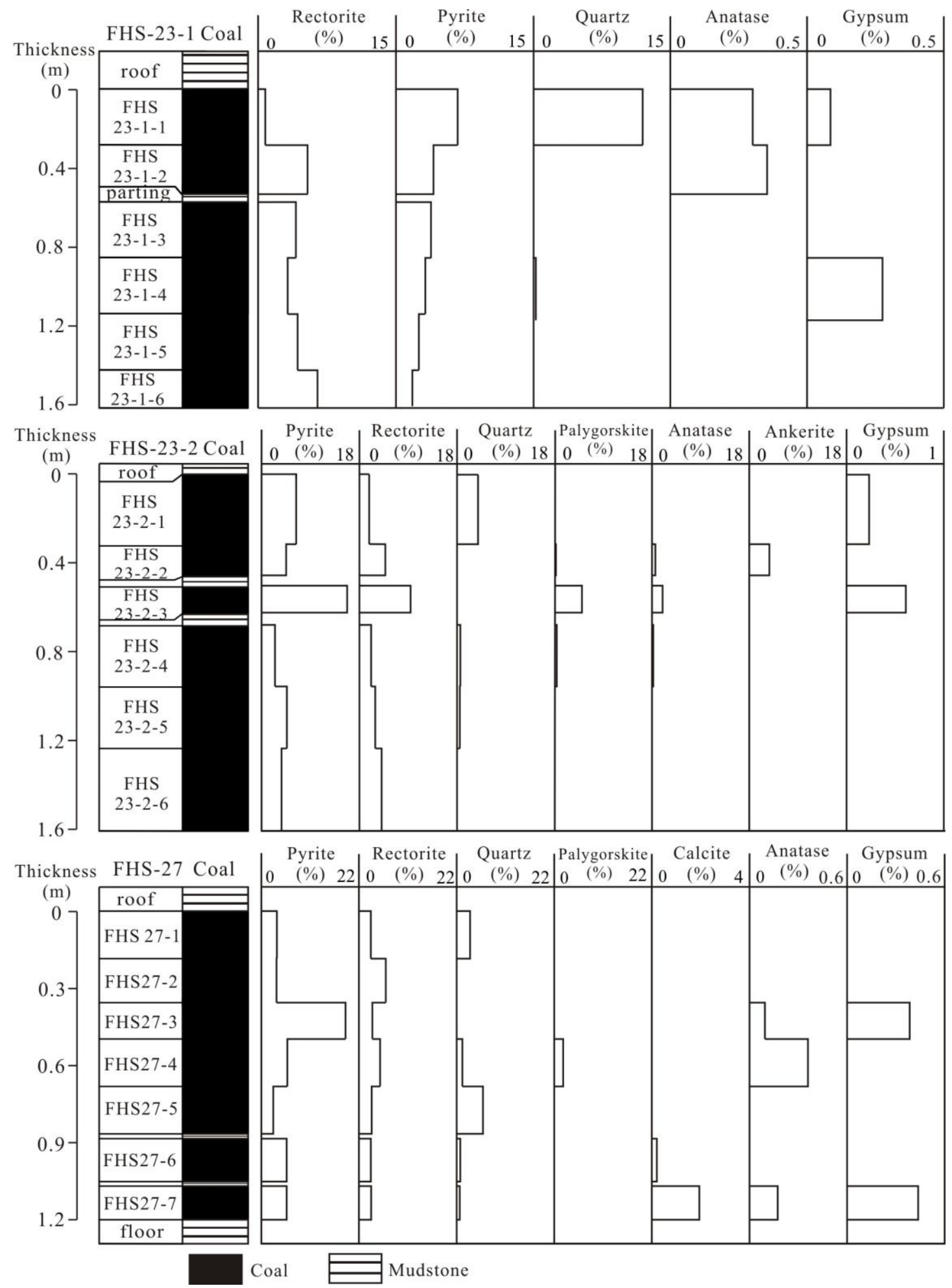

Fig. 3 Vertical variations of minerals through the FHS-23 and FHS-27 Coal sections in the Fenghuangshan underground coal mine of the Zhina Coalfield 


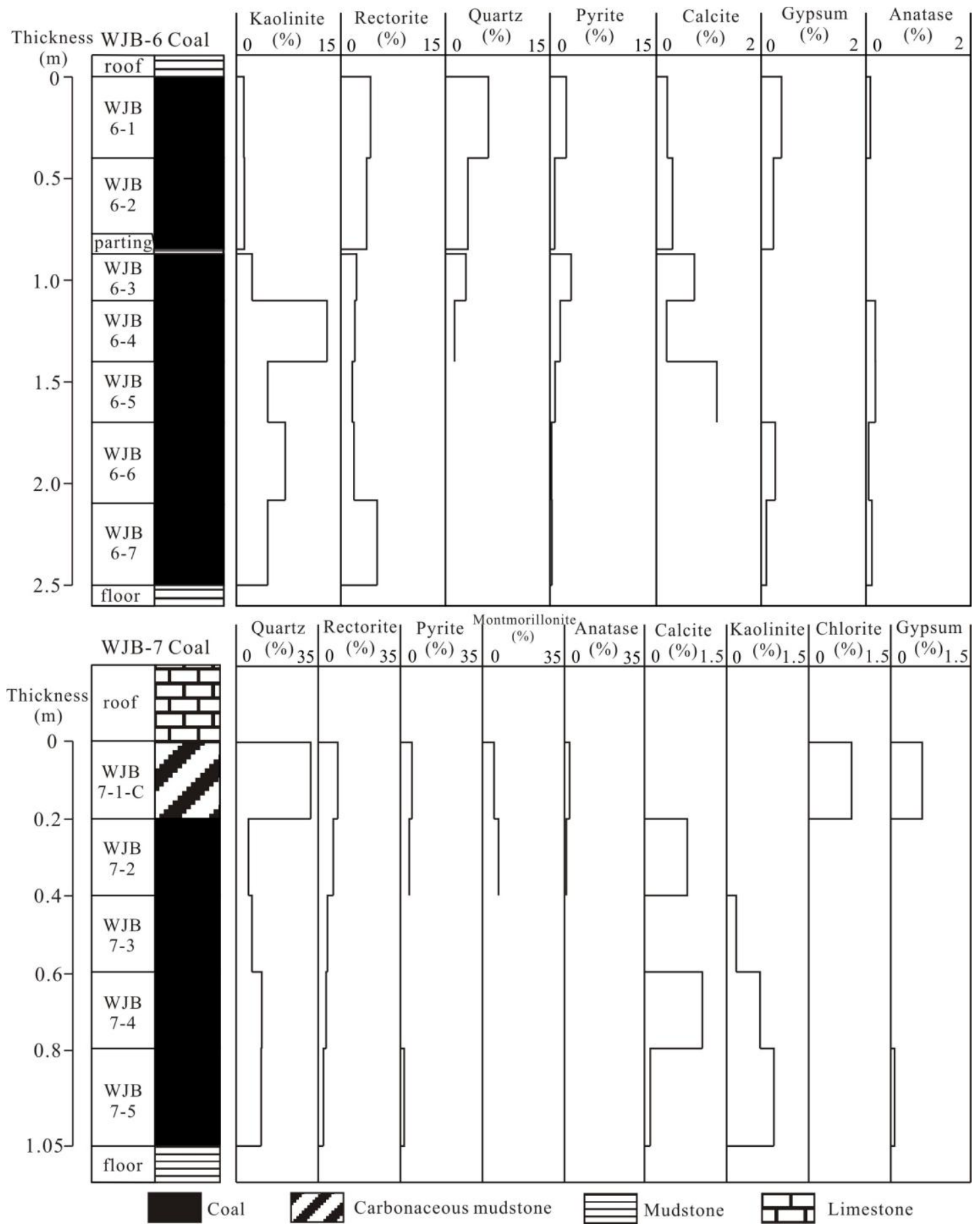

Fig. 4 Vertical variations of minerals through the WJB-6 and WJB-7 Coal sections in the Wenjiaba underground coal mine of the Zhina Coalfield 

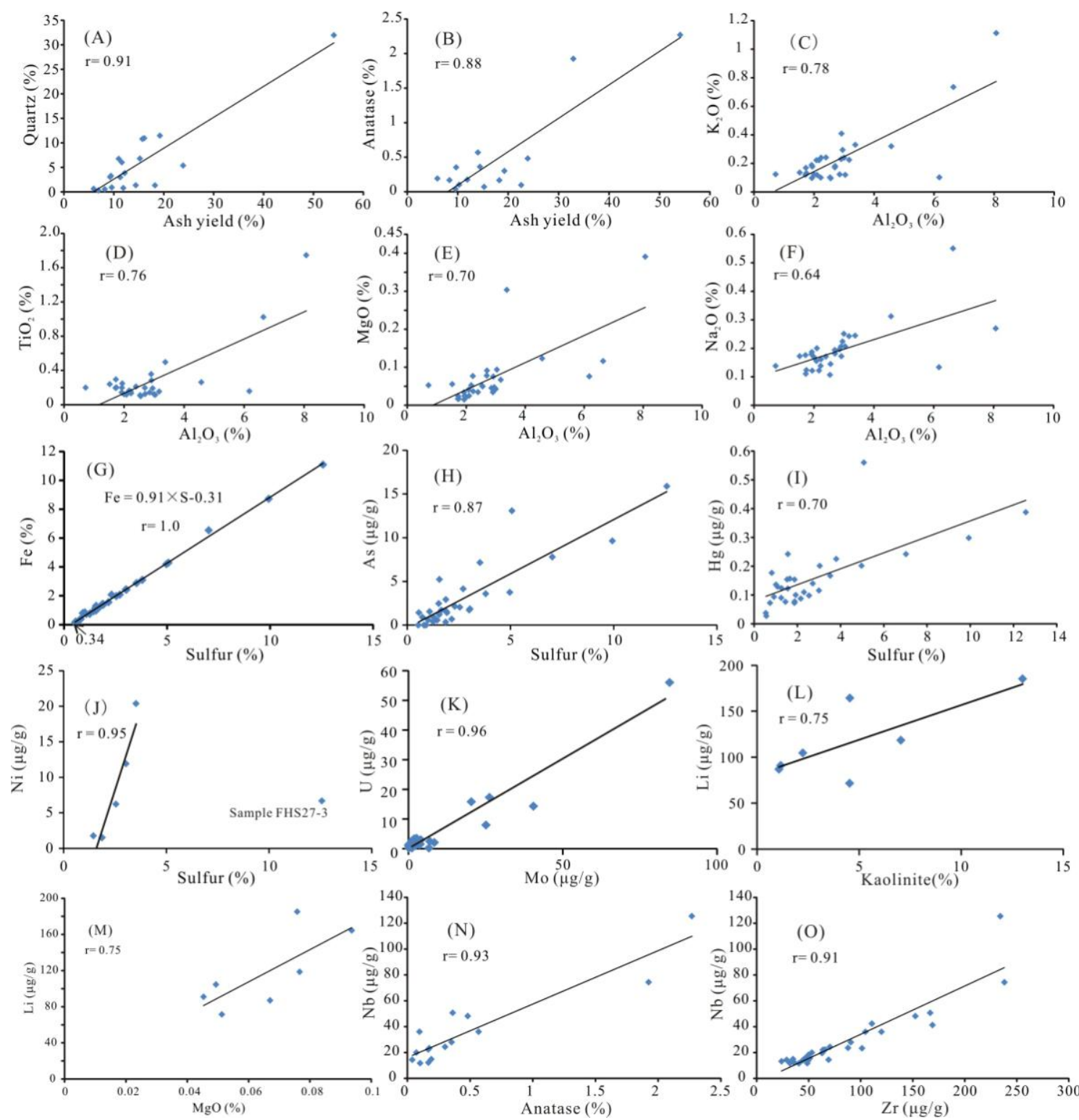

Fig. 5 The correlation coefficients between selective elements or minerals 

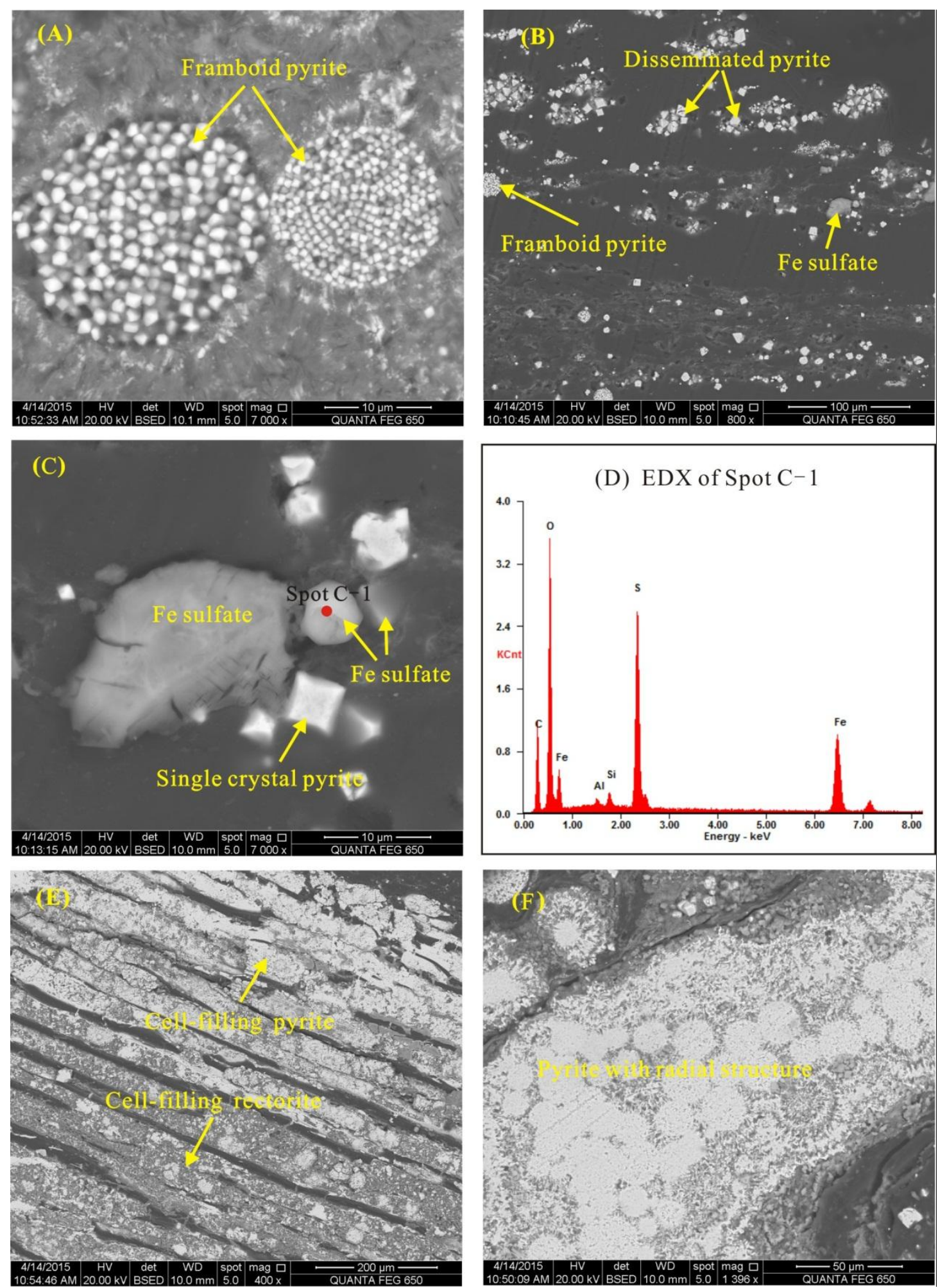

Fig. 6 SEM backscattered images and selected EDX data of crystalline phases in sample FHS23-2-3. (A) Spherical polycrystalline framboid pyrite; (B) Disseminated pyrite and sulfate mineral; (C) Single pyrite crystal pyrite and Fe sulfate filling the cavities of organic matrix; (D) EDX data for Fe sulfate; (E) Cell-filling pyrite and rectorite; (F) Spherical pyrite with radial structure. 

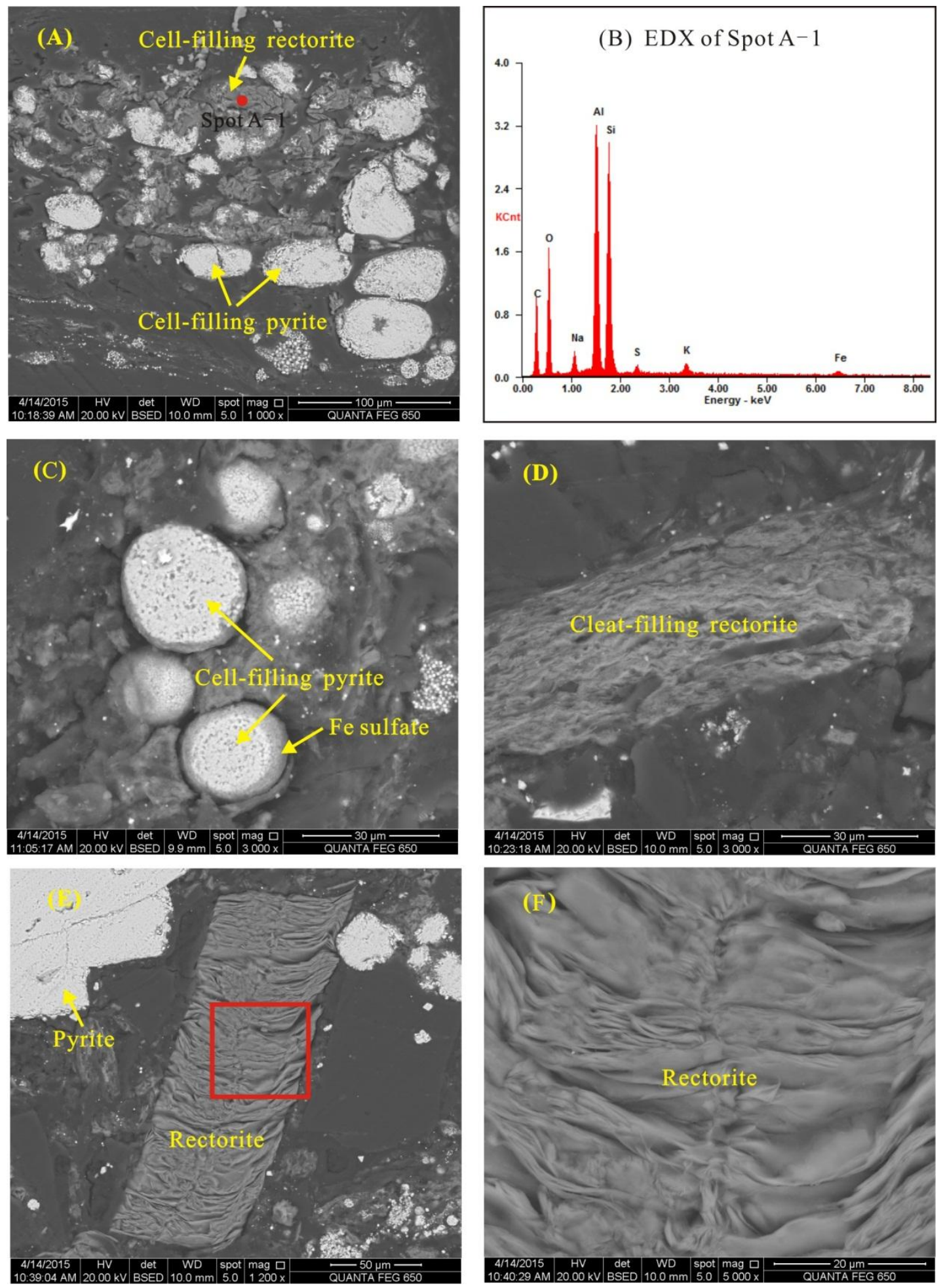

Fig. 7 SEM backscattered images and selected EDX data of crystalline phases in sample FHS23-2-3. (A) Cell-filling pyrite and rectorite; (B) EDX data for rectorite; (C) Cell-filling pyrite bounded by late generation of Fe sulfate; (D) Cleat-filling rectorite; (E) Cleat-filling rectorite and pyrite; (F) Enlargement of the red square in (E). 

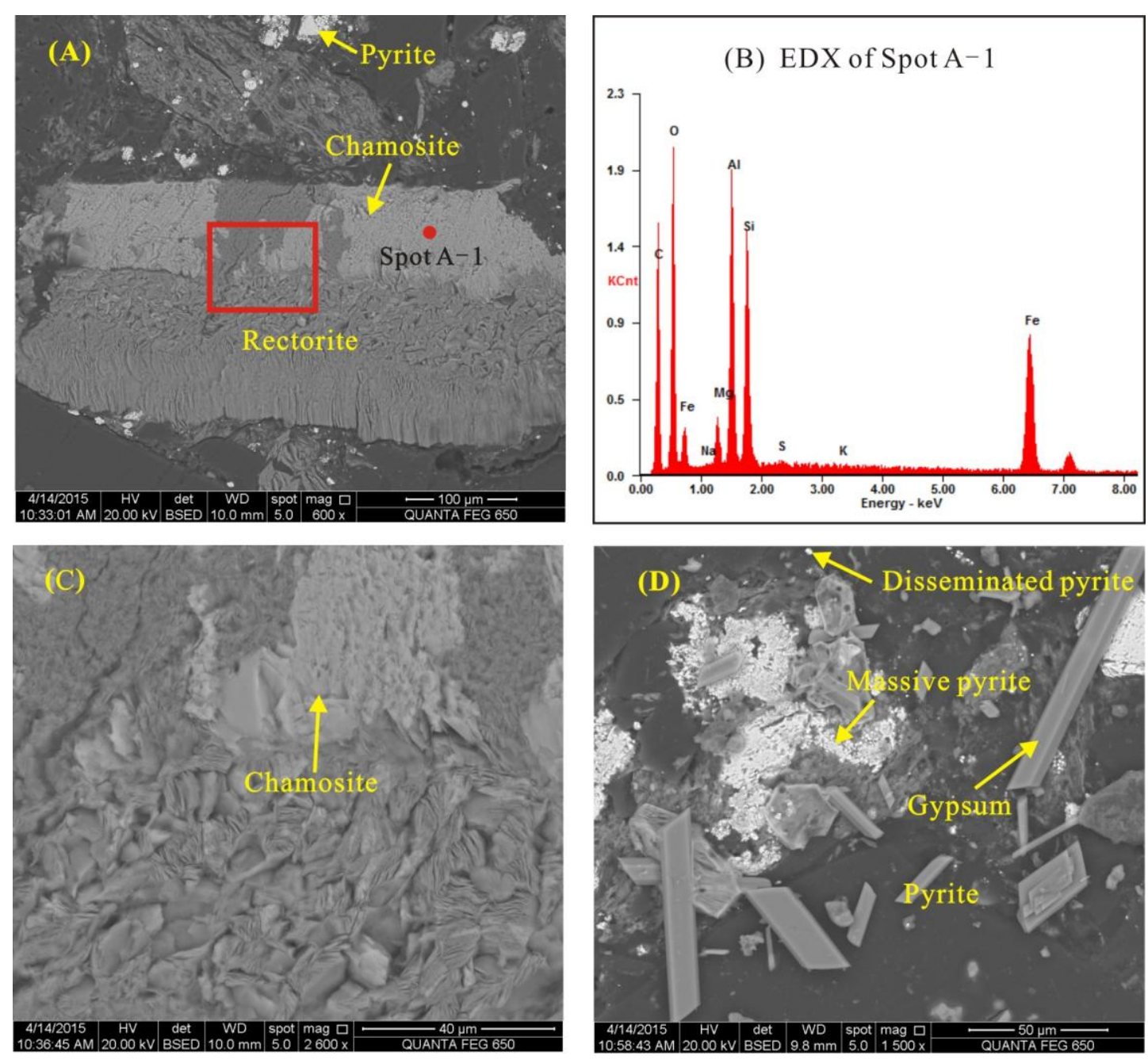

Fig. 8 SEM backscattered images and selected EDX data of crystalline phases in sample WJB6-1. (A) Cleat-filling chamosite and rectorite as well as disseminated pyrite; (B) EDX data for chamosite; (C) Enlargement of the red square in (A); (D) Massive pyrite as well as disseminated pyrite and gypsum. 

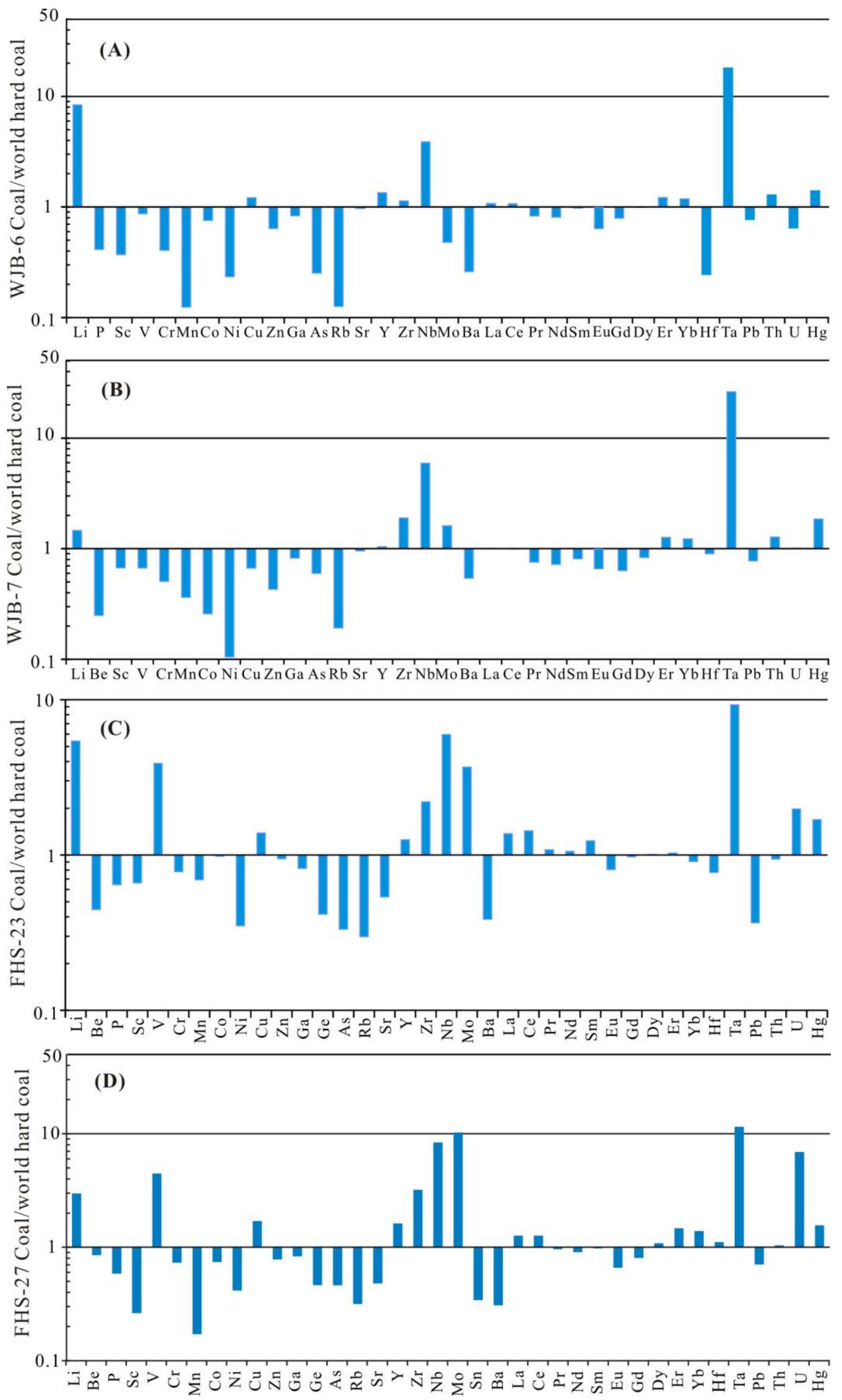

Fig. 9 Concentration coefficients (CC) of trace elements in the WJB-6 Coal (A), WJB-7 Coal (B), FHS-23 Coal (C) and FHS-27 Coal (D). Normalized by the average abundance in the world hard coals (Ketris and Yudovich, 2009). 


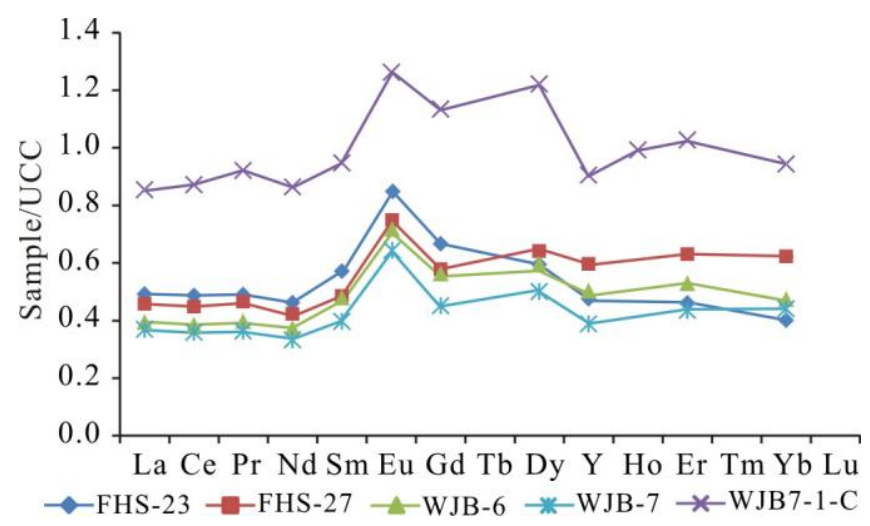

Fig. 10 The REY distribution patterns of the FHS-23, FHS-27, WJB-6 and WJB-7 Coals as well as carbonaceous mudstone (sample WJB7-1-C). REY are normalized to Upper Continental Crust (UCC) (Taylor and McLennan, 1985) 


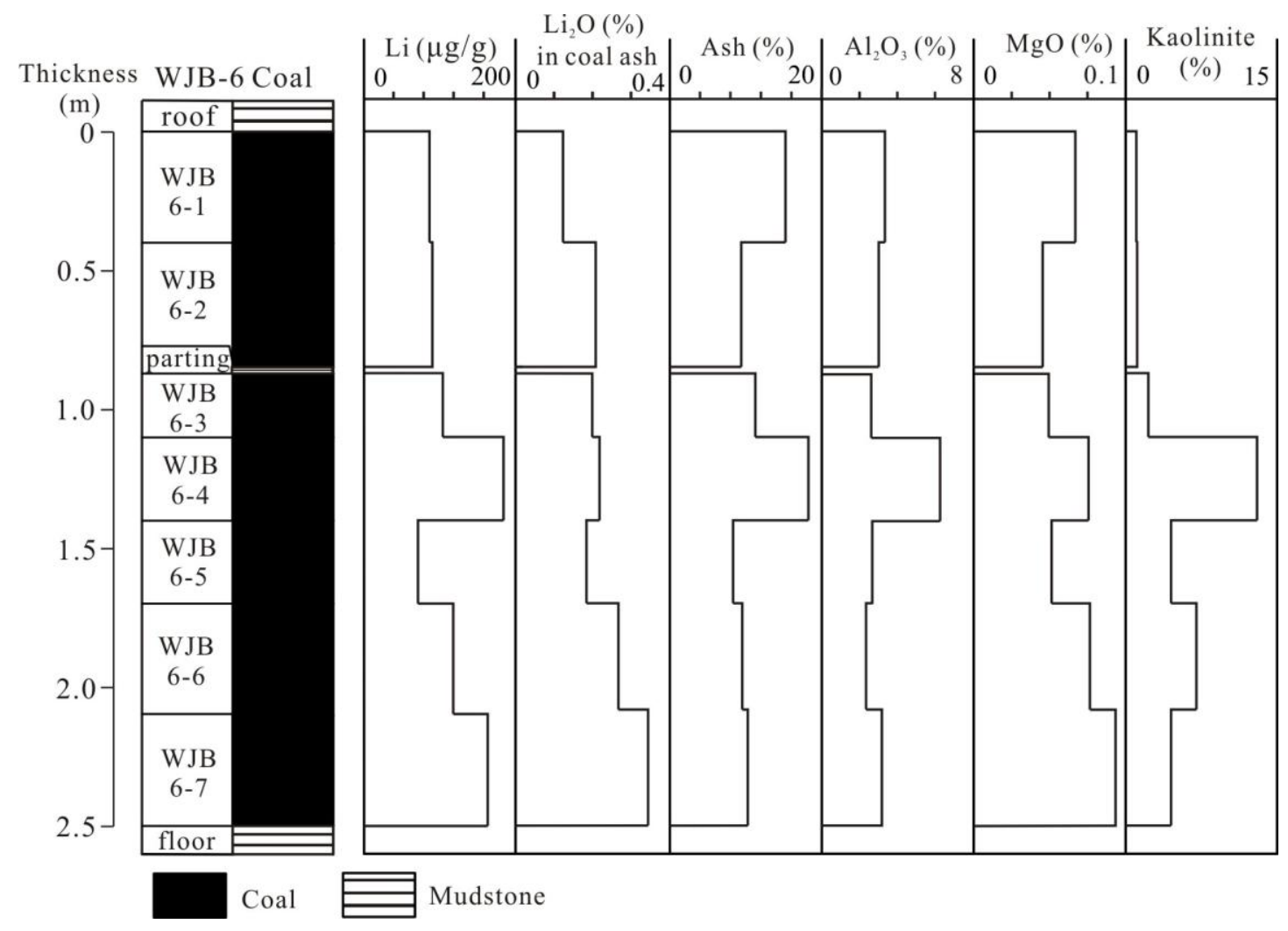

Fig. 11 The vertical distributions of $\mathrm{Li}, \mathrm{Li}_{2} \mathrm{O}, \mathrm{Ash}, \mathrm{Al}_{2} \mathrm{O}_{3}, \mathrm{MgO}$ and kaolinite abundances in the WJB-6 Coal 
Table 1 Proximate analysis and sulfur contents of the coals and carbonaceous mudstone (sampleWJB7-1-C) in the Zhina Coalfield

\begin{tabular}{|c|c|c|c|c|c|c|c|}
\hline Coal mine & Coal seam & Sample & $\begin{array}{l}\text { Thickness } \\
\text { (m) }\end{array}$ & $\begin{array}{c}\text { Moisture } \\
\text { (ad,\%) }\end{array}$ & $\begin{array}{l}\text { Ash } \\
(\mathrm{d}, \%)\end{array}$ & $\begin{array}{c}\text { Volatile matter } \\
(\text { daf }, \%)\end{array}$ & $\begin{array}{l}\text { Sulfur } \\
\text { (ad, \%) }\end{array}$ \\
\hline \multirow{19}{*}{$\begin{array}{c}\text { Fenghuangshan } \\
\text { underground } \\
\text { coal mine }\end{array}$} & \multirow{12}{*}{$\begin{array}{l}\text { FHS-23 } \\
\text { Coal }\end{array}$} & FHS23-1-1 & 0.30 & 2.29 & 19.24 & 8.31 & 4.97 \\
\hline & & FHS23-1-2 & 0.26 & 2.65 & 9.70 & 7.10 & 1.56 \\
\hline & & FHS23-1-3 & 0.30 & 3.24 & 7.83 & 4.92 & 2.16 \\
\hline & & FHS23-1-4 & 0.30 & 2.97 & 6.90 & 5.89 & 1.65 \\
\hline & & FHS23-1-5 & 0.30 & 3.13 & 6.66 & 6.29 & 1.27 \\
\hline & & FHS23-1-6 & 0.20 & 3.06 & 8.16 & 6.38 & 0.82 \\
\hline & & FHS23-2-1 & 0.35 & 2.83 & 12.17 & 7.34 & 3.80 \\
\hline & & FHS23-2-2 & 0.15 & 3.00 & 14.01 & 8.55 & 2.31 \\
\hline & & FHS23-2-3 & 0.13 & 2.63 & 32.91 & 12.69 & 9.94 \\
\hline & & FHS23-2-4 & 0.30 & 2.75 & 5.98 & 5.70 & 1.26 \\
\hline & & FHS23-2-5 & 0.30 & 2.55 & 8.18 & 5.86 & 2.71 \\
\hline & & FHS23-2-6 & 0.40 & 2.60 & 7.87 & 5.74 & 1.92 \\
\hline & \multirow{7}{*}{$\begin{array}{c}\text { FHS-27 } \\
\text { Coal }\end{array}$} & FHS27-1 & 0.20 & 3.56 & 9.27 & 6.25 & 1.86 \\
\hline & & FHS27-2 & 0.20 & 3.24 & 9.48 & 6.43 & 1.45 \\
\hline & & FHS27-3 & 0.14 & 3.50 & 22.59 & 14.30 & 12.57 \\
\hline & & FHS27-4 & 0.20 & 3.24 & 14.41 & 7.87 & 3.04 \\
\hline & & FHS27-5 & 0.20 & 3.60 & 11.60 & 7.33 & 1.88 \\
\hline & & FHS27-6 & 0.18 & 2.85 & 9.61 & 7.35 & 2.54 \\
\hline & & FHS27-7 & 0.14 & 3.08 & 11.88 & 7.93 & 3.52 \\
\hline \multirow{12}{*}{$\begin{array}{l}\text { Wenjiaba } \\
\text { underground } \\
\text { coal mine }\end{array}$} & \multirow{7}{*}{$\begin{array}{l}\text { WJB-6 } \\
\text { Coal }\end{array}$} & WJB6-1 & 0.40 & 2.89 & 15.24 & 9.20 & 1.53 \\
\hline & & WJB6-2 & 0.45 & 2.83 & 9.43 & 6.96 & 0.74 \\
\hline & & WJB6-3 & 0.23 & 2.92 & 11.29 & 7.69 & 1.87 \\
\hline & & WJB6-4 & 0.30 & 2.72 & 18.25 & 12.02 & 1.56 \\
\hline & & WJB6-5 & 0.30 & 3.10 & 8.35 & 7.25 & 1.08 \\
\hline & & WJB6-6 & 0.40 & 3.06 & 9.55 & 7.50 & 1.02 \\
\hline & & WJB6-7 & 0.40 & 3.16 & 10.28 & 7.45 & 0.92 \\
\hline & \multirow{5}{*}{$\begin{array}{l}\text { WJB-7 } \\
\text { Coal }\end{array}$} & WJB7-1-C & 0.20 & 3.03 & 54.10 & 16.09 & 7.03 \\
\hline & & WJB7-2 & 0.20 & 3.09 & 23.88 & 10.52 & 5.08 \\
\hline & & WJB7-3 & 0.20 & 3.03 & 10.98 & 6.88 & 0.54 \\
\hline & & WJB7-4 & 0.20 & 2.98 & 16.10 & 7.47 & 0.57 \\
\hline & & WJB7-5 & 0.25 & 2.70 & 15.74 & 8.36 & 3.00 \\
\hline
\end{tabular}

ad, air dry basis; d-dry basis; daf, dry and ash-free basis. 
Table 2 Mineralogical proportions of the coals and carbonaceous mudstone (sample WJB7-1-C) determined by XRD from the Zhina Coalfield (on whole-coal basis; unit in \%)

\begin{tabular}{|c|c|c|c|c|c|c|c|c|c|c|c|c|}
\hline Coal Seam & Sample & Mont & Kln & Chl & Pal & Rect & Qtz & Ant & $\mathrm{Cal}$ & Ank & $\mathrm{Py}$ & $\mathrm{Gp}$ \\
\hline \multirow{12}{*}{$\begin{array}{c}\text { FHS-23 } \\
\text { Coal }\end{array}$} & FHS23-1-1 & $<\mathrm{dl}$ & $<\mathrm{dl}$ & $<\mathrm{dl}$ & $<\mathrm{dl}$ & 0.8 & 11.5 & 0.3 & $<\mathrm{dl}$ & $<\mathrm{dl}$ & 6.6 & 0.1 \\
\hline & FHS23-1-2 & $<\mathrm{dl}$ & $<\mathrm{dl}$ & $<\mathrm{dl}$ & $<\mathrm{dl}$ & 5.3 & $<\mathrm{dl}$ & 0.4 & $<\mathrm{dl}$ & $<\mathrm{dl}$ & 4.1 & $<\mathrm{dl}$ \\
\hline & FHS23-1-3 & $<\mathrm{dl}$ & $<\mathrm{dl}$ & $<\mathrm{dl}$ & $<\mathrm{dl}$ & 4.1 & $<\mathrm{dl}$ & $<\mathrm{dl}$ & $<\mathrm{dl}$ & $<\mathrm{dl}$ & 3.8 & $<\mathrm{dl}$ \\
\hline & FHS23-1-4 & $<\mathrm{dl}$ & $<\mathrm{dl}$ & $<\mathrm{dl}$ & $<\mathrm{dl}$ & 3.2 & 0.3 & $<\mathrm{dl}$ & $<\mathrm{dl}$ & $<\mathrm{dl}$ & 3.2 & 0.3 \\
\hline & FHS23-1-5 & $<\mathrm{dl}$ & $<\mathrm{dl}$ & $<\mathrm{dl}$ & $<\mathrm{dl}$ & 4.2 & $<\mathrm{dl}$ & $<\mathrm{dl}$ & $<\mathrm{dl}$ & $<\mathrm{dl}$ & 2.4 & $<\mathrm{dl}$ \\
\hline & FHS23-1-6 & $<\mathrm{dl}$ & $<\mathrm{dl}$ & $<\mathrm{dl}$ & $<\mathrm{dl}$ & 6.3 & $<\mathrm{dl}$ & $<\mathrm{dl}$ & $<\mathrm{dl}$ & $<\mathrm{dl}$ & 1.8 & $<\mathrm{dl}$ \\
\hline & FHS23-2-1 & $<\mathrm{dl}$ & $<\mathrm{dl}$ & $<\mathrm{dl}$ & $<\mathrm{dl}$ & 1.7 & 3.8 & $<\mathrm{dl}$ & $<\mathrm{dl}$ & $<\mathrm{dl}$ & 6.5 & 0.2 \\
\hline & FHS23-2-2 & $<\mathrm{dl}$ & $<\mathrm{dl}$ & $<\mathrm{dl}$ & 0.3 & 4.8 & $<\mathrm{dl}$ & 0.6 & $<\mathrm{dl}$ & 3.7 & 4.6 & $<\mathrm{dl}$ \\
\hline & FHS23-2-3 & $<\mathrm{dl}$ & $<\mathrm{dl}$ & $<\mathrm{dl}$ & 5.1 & 9.5 & $<\mathrm{dl}$ & 1.9 & $<\mathrm{dl}$ & $<\mathrm{dl}$ & 15.8 & 0.6 \\
\hline & FHS23-2-4 & $<\mathrm{dl}$ & $<\mathrm{dl}$ & $<\mathrm{dl}$ & 0.4 & 2.2 & 0.6 & 0.2 & $<\mathrm{dl}$ & $<\mathrm{dl}$ & 2.5 & $<\mathrm{dl}$ \\
\hline & FHS23-2-5 & $<\mathrm{dl}$ & $<\mathrm{dl}$ & $<\mathrm{dl}$ & $<\mathrm{dl}$ & 3.0 & 0.5 & $<\mathrm{dl}$ & $<\mathrm{dl}$ & $<\mathrm{dl}$ & 4.7 & $<\mathrm{dl}$ \\
\hline & FHS23-2-6 & $<\mathrm{dl}$ & $<\mathrm{dl}$ & $<\mathrm{dl}$ & $<\mathrm{dl}$ & 4.2 & $<\mathrm{dl}$ & $<\mathrm{dl}$ & $<\mathrm{dl}$ & $<\mathrm{dl}$ & 3.7 & $<\mathrm{dl}$ \\
\hline \multirow{7}{*}{$\begin{array}{c}\text { FHS-27 } \\
\text { Coal }\end{array}$} & FHS27-1 & $<\mathrm{dl}$ & $<\mathrm{dl}$ & $<\mathrm{dl}$ & $<\mathrm{dl}$ & 2.7 & 3.0 & $<\mathrm{dl}$ & $<\mathrm{dl}$ & $<\mathrm{dl}$ & 3.5 & $<\mathrm{dl}$ \\
\hline & FHS27-2 & $<\mathrm{dl}$ & $<\mathrm{dl}$ & $<\mathrm{dl}$ & $<\mathrm{dl}$ & 6.1 & $<\mathrm{dl}$ & $<\mathrm{dl}$ & $<\mathrm{dl}$ & $<\mathrm{dl}$ & 3.4 & $<\mathrm{dl}$ \\
\hline & FHS27-3 & $<\mathrm{dl}$ & $<\mathrm{dl}$ & $<\mathrm{dl}$ & $<\mathrm{dl}$ & 3.1 & $<\mathrm{dl}$ & 0.1 & $<\mathrm{dl}$ & $<\mathrm{dl}$ & 19.0 & 0.4 \\
\hline & FHS27-4 & $<\mathrm{dl}$ & $<\mathrm{dl}$ & $<\mathrm{dl}$ & 2.0 & 4.8 & 1.4 & 0.4 & $<\mathrm{dl}$ & $<\mathrm{dl}$ & 5.9 & $<\mathrm{dl}$ \\
\hline & FHS27-5 & $<\mathrm{dl}$ & $<\mathrm{dl}$ & $<\mathrm{dl}$ & $<\mathrm{dl}$ & 2.9 & 6.0 & $<\mathrm{dl}$ & $<\mathrm{dl}$ & $<\mathrm{dl}$ & 2.7 & $<\mathrm{dl}$ \\
\hline & FHS27-6 & $<\mathrm{dl}$ & $<\mathrm{dl}$ & $<\mathrm{dl}$ & $<\mathrm{dl}$ & 2.7 & 0.9 & $<\mathrm{dl}$ & 0.2 & $<\mathrm{dl}$ & 5.7 & $<\mathrm{dl}$ \\
\hline & FHS27-7 & $<\mathrm{dl}$ & $<\mathrm{dl}$ & $<\mathrm{dl}$ & $<\mathrm{dl}$ & 2.8 & 0.8 & 0.2 & 2.0 & $<\mathrm{dl}$ & 5.8 & 0.4 \\
\hline \multirow{7}{*}{$\begin{array}{r}\text { WJB-6 } \\
\text { Coal }\end{array}$} & WJB6-1 & $<\mathrm{dl}$ & 1.1 & $<\mathrm{dl}$ & $<\mathrm{dl}$ & 4.3 & 6.8 & 0.1 & 0.2 & $<\mathrm{dl}$ & 2.4 & 0.4 \\
\hline & WJB6-2 & $<\mathrm{dl}$ & 1.2 & $<\mathrm{dl}$ & $<\mathrm{dl}$ & 3.7 & 3.3 & $<\mathrm{dl}$ & 0.3 & $<\mathrm{dl}$ & 0.7 & 0.2 \\
\hline & WJB6-3 & $<\mathrm{dl}$ & 2.2 & $<\mathrm{dl}$ & $<\mathrm{dl}$ & 2.2 & 3.0 & $<\mathrm{dl}$ & 0.7 & $<\mathrm{dl}$ & 3.1 & $<\mathrm{dl}$ \\
\hline & WJB6-4 & $<\mathrm{dl}$ & 13.0 & $<\mathrm{dl}$ & $<\mathrm{dl}$ & 2.0 & 1.3 & 0.2 & 0.2 & $<\mathrm{dl}$ & 1.5 & $<\mathrm{dl}$ \\
\hline & WJB6-5 & $<\mathrm{dl}$ & 4.5 & $<\mathrm{dl}$ & $<\mathrm{dl}$ & 1.7 & $<\mathrm{dl}$ & 0.2 & 1.2 & $<\mathrm{dl}$ & 0.8 & $<\mathrm{dl}$ \\
\hline & WJB6-6 & $<\mathrm{dl}$ & 7.0 & $<\mathrm{dl}$ & $<\mathrm{dl}$ & 1.9 & $<\mathrm{dl}$ & 0.0 & $<\mathrm{dl}$ & $<\mathrm{dl}$ & 0.3 & 0.3 \\
\hline & WJB6-7 & $<\mathrm{dl}$ & 4.6 & $<\mathrm{dl}$ & $<\mathrm{dl}$ & 5.2 & $<\mathrm{dl}$ & 0.1 & $<\mathrm{dl}$ & $<\mathrm{dl}$ & 0.3 & 0.1 \\
\hline \multirow{5}{*}{$\begin{array}{r}\text { WJB-7 } \\
\text { Coal }\end{array}$} & WJB7-1-C & 5.0 & $<\mathrm{dl}$ & 0.8 & $<\mathrm{dl}$ & 8.4 & 31.9 & 2.3 & $<\mathrm{dl}$ & $<\mathrm{dl}$ & 5.0 & 0.6 \\
\hline & WJB7-2 & 7.0 & $<\mathrm{dl}$ & $<\mathrm{dl}$ & $<\mathrm{dl}$ & 6.4 & 5.4 & 0.5 & 0.8 & $<\mathrm{dl}$ & 3.9 & $<\mathrm{dl}$ \\
\hline & WJB7-3 & $<\mathrm{dl}$ & 0.2 & $<\mathrm{dl}$ & $<\mathrm{dl}$ & 4.0 & 6.7 & $<\mathrm{dl}$ & $<\mathrm{dl}$ & $<\mathrm{dl}$ & $<\mathrm{dl}$ & $<\mathrm{dl}$ \\
\hline & WJB7-4 & $<\mathrm{dl}$ & 0.6 & $<\mathrm{dl}$ & $<\mathrm{dl}$ & 3.4 & 10.9 & $<\mathrm{dl}$ & 1.1 & $<\mathrm{dl}$ & $<\mathrm{dl}$ & $<\mathrm{dl}$ \\
\hline & WJB7-5 & $<\mathrm{dl}$ & 0.9 & $<\mathrm{dl}$ & $<\mathrm{dl}$ & 2.2 & 10.8 & $<\mathrm{dl}$ & 0.1 & $<\mathrm{dl}$ & 1.6 & 0.1 \\
\hline
\end{tabular}

Mont, montmorillonite; Pal, palygorskite; Kln, kaolinite; Chl, chlorite; Rect, rectorite; Qtz, quartz; Ant, anatase; Ank, ankerite; Cal, calcite; Py, pyrite; Gp, gypsum; <dl, below detection limit. 
Table 3 Major-element oxides (\%) and trace element concentrations $(\mu \mathrm{g} / \mathrm{g})$ of the WJB-6 and WJB-7 Coals as well as the carbonaceous mudstone (sample WJB7-1-C) in the Wenjiaba underground coal mine (on whole-coal basis).

\begin{tabular}{|c|c|c|c|c|c|c|c|c|c|c|c|c|}
\hline & & & & & & & & & & & & \\
\hline & WIB6-1 & WIB6-2 & WIB6-3 & WIB6-4 & WIB6-5 & WIB6-6 & WIB6-7 & WIB 7-1-C & WIB 7-2 & WIB 7-3 & WIB 7-4 & WIB 7-5 \\
\hline $\mathrm{SiO}_{2}$ & 9.3 & 5.5 & 5.1 & 8.4 & 2.9 & 4.2 & 5 & 38 & 11 & 8.7 & 13 & 12 \\
\hline $\mathrm{TiO}_{2}$ & 0.15 & 0.14 & 0.10 & 0.16 & 0.11 & 0.15 & 0.12 & 1.74 & 0.26 & 0.20 & 0.12 & 0.20 \\
\hline $\mathrm{Al}_{2} \mathrm{O}_{3}$ & 3.2 & 2.9 & 2.6 & 6.2 & 2.5 & 2.2 & 3.0 & 8.1 & 4.6 & 2.7 & 2.7 & 0.72 \\
\hline $\mathrm{Fe}_{2} \mathrm{O}_{3}$ & 1.6 & 0.44 & 2.1 & 1.9 & 1.04 & 1.20 & 1.14 & 9.3 & 6.1 & 0.16 & 0.29 & 3.5 \\
\hline $\mathrm{MgO}$ & 0.07 & 0.05 & 0.05 & 0.08 & 0.05 & 0.08 & 0.09 & 0.39 & 0.12 & 0.08 & 0.09 & 0.05 \\
\hline $\mathrm{CaO}$ & 0.29 & 0.14 & 0.35 & 0.20 & 0.41 & 0.10 & 0.06 & 0.27 & 0.20 & 0.14 & 0.81 & 0.23 \\
\hline $\mathrm{Na}_{2} \mathrm{O}$ & 0.24 & 0.20 & 0.14 & 0.13 & 0.11 & 0.14 & 0.21 & 0.27 & 0.31 & 0.19 & 0.18 & 0.14 \\
\hline $\mathrm{K}_{2} \mathrm{O}$ & 0.22 & 0.12 & 0.10 & 0.10 & 0.10 & 0.10 & 0.12 & 1.11 & 0.32 & 0.17 & 0.18 & 0.12 \\
\hline $\mathrm{Li}$ & 87 & 91 & 105 & 185 & 72 & 119 & 164 & 33 & 28 & 13 & 16 & 25 \\
\hline $\mathrm{Be}$ & $<\mathrm{dl}$ & $<\mathrm{dl}$ & $<\mathrm{dl}$ & $<\mathrm{dl}$ & $<\mathrm{dl}$ & $<\mathrm{dl}$ & $<\mathrm{dl}$ & 1.8 & 0.80 & $<\mathrm{dl}$ & $<\mathrm{dl}$ & 0.20 \\
\hline $\mathrm{P}$ & $<\mathrm{dl}$ & $<\mathrm{dl}$ & $<\mathrm{dl}$ & 1.0 & 104 & 205 & $<\mathrm{dl}$ & $<\mathrm{dl}$ & $<\mathrm{dl}$ & $<\mathrm{dl}$ & $<\mathrm{dl}$ & $<\mathrm{dl}$ \\
\hline Sc & 1.8 & 1.4 & 0.87 & 1.6 & 1.1 & 1.5 & 1.4 & 11.4 & 3.5 & 1.5 & $<\mathrm{dl}$ & $<\mathrm{dl}$ \\
\hline $\mathrm{V}$ & 69 & 23 & 11 & 19 & 14 & 16 & 19 & 136 & 20 & 17 & 15 & 22 \\
\hline $\mathrm{Cr}$ & 9.4 & 7.6 & 5.2 & 6.8 & 5.6 & 6.7 & 6.9 & 74 & 10 & 10 & 6.4 & 7.7 \\
\hline $\mathrm{Mn}$ & 12 & 5.1 & 9.5 & 20 & 8.6 & 2.9 & 3.2 & 52 & 14 & 8.3 & 70 & 11 \\
\hline $\mathrm{Co}$ & 4.1 & 3.4 & 3.0 & 8.2 & 4.7 & 3.9 & 4.5 & 18 & 2.1 & 0.92 & $<\mathrm{dl}$ & 1.6 \\
\hline $\mathrm{Ni}$ & 2.9 & 3.2 & 2.9 & 8.0 & 3.4 & 3.1 & 4.3 & 25 & 2.2 & 1.4 & 1.4 & 2.1 \\
\hline $\mathrm{Cu}$ & 43 & 13 & 8.3 & 17 & 19 & 16 & 19 & 35 & 30 & 2.2 & 1.9 & 8.3 \\
\hline $\mathrm{Zn}$ & 29 & 6.5 & $<\mathrm{dl}$ & 18 & 4.0 & 37 & 13 & 30 & 29 & 15 & 3.0 & 1.7 \\
\hline $\mathrm{Ga}$ & 5.1 & 3.7 & 3.9 & 7.2 & 5.1 & 4.6 & 5.5 & 13 & 8.8 & 3.9 & 4.7 & 2.4 \\
\hline $\mathrm{Ge}$ & $<\mathrm{dl}$ & $<\mathrm{dl}$ & $<\mathrm{dl}$ & $<\mathrm{dl}$ & $<\mathrm{dl}$ & $<\mathrm{dl}$ & $<\mathrm{dl}$ & 1.1 & $<\mathrm{dl}$ & $<\mathrm{dl}$ & $<\mathrm{dl}$ & $<\mathrm{dl}$ \\
\hline As & 2.5 & 0.89 & 2.9 & 5.2 & 1.5 & 0.60 & $<\mathrm{dl}$ & 7.8 & 13.07 & $<\mathrm{dl}$ & 1.4 & 1.7 \\
\hline $\mathrm{Rb}$ & 3.9 & 2.1 & 1.9 & 2.0 & 2.2 & 1.8 & 2.0 & 27.09 & 6.5 & 3.0 & 3.2 & 1.1 \\
\hline $\mathrm{Sr}$ & 106 & 85 & 111 & 84 & 68 & 142 & 83 & 255 & 132 & 87 & 109 & 54 \\
\hline $\mathrm{Y}$ & 9.1 & 8.4 & 7.8 & 10 & 12 & 16 & 14 & 20 & 12 & 8.1 & 9.4 & 4.8 \\
\hline $\mathrm{Zr}$ & 53 & 35 & 35 & 66 & 36 & 29 & 32 & 234 & 153 & 50 & 46 & 24 \\
\hline $\mathrm{Nb}$ & 20 & 15 & 13 & 22 & 12 & 14 & 12 & 125 & 48 & 18 & 15 & 13 \\
\hline Mo & $<\mathrm{dl}$ & $<\mathrm{dl}$ & 0.84 & 1.2 & $<\mathrm{dl}$ & $<\mathrm{dl}$ & $<\mathrm{dl}$ & 2.0 & 4.1 & $<\mathrm{dl}$ & 2.7 & $<\mathrm{dl}$ \\
\hline $\mathrm{Sn}$ & 0.93 & 0.43 & 0.64 & 1.5 & 0.38 & 0.44 & 0.43 & 1.4 & 1.8 & 0.50 & 0.76 & 0.48 \\
\hline Cs & $<\mathrm{dl}$ & $<\mathrm{dl}$ & $<\mathrm{dl}$ & $<\mathrm{dl}$ & $<\mathrm{dl}$ & $<\mathrm{dl}$ & $<\mathrm{dl}$ & 0.99 & $<\mathrm{dl}$ & $<\mathrm{dl}$ & $<\mathrm{dl}$ & $<\mathrm{dl}$ \\
\hline $\mathrm{Ba}$ & 64 & 40 & 35 & 44 & 31 & 30 & 29 & 320 & 142 & 73 & 72 & 37 \\
\hline $\mathrm{La}$ & 11 & 11 & 9.6 & 11 & 12 & 18 & 10 & 26 & 15 & 12 & 12 & 5.0 \\
\hline $\mathrm{Ce}$ & 23 & 22 & 18 & 24 & 26 & 35 & 24 & 56 & 30 & 25 & 26 & 11 \\
\hline $\operatorname{Pr}$ & 2.7 & 2.5 & 2.0 & 2.7 & 3.0 & 3.9 & 2.9 & 6.5 & 3.2 & 2.7 & 3.0 & 1.4 \\
\hline $\mathrm{Nd}$ & 9.4 & 8.6 & 6.6 & 8.9 & 10 & 13 & 10 & 22 & 10 & 8.8 & 11 & 5.1 \\
\hline $\mathrm{Sm}$ & 2.0 & 1.8 & 1.5 & 2.0 & 2.4 & 3.1 & 2.4 & 4.3 & 2.1 & 1.7 & 2.2 & 1.1 \\
\hline $\mathrm{Eu}$ & 0.68 & 0.62 & 0.66 & 0.66 & 0.64 & 0.60 & 0.61 & 1.10 & 0.59 & 0.63 & 0.61 & 0.60 \\
\hline $\mathrm{Gd}$ & 1.9 & 1.7 & 1.5 & 1.8 & 2.3 & 3.3 & 2.6 & 4.3 & 2.2 & 1.6 & 2.0 & 1.1 \\
\hline $\mathrm{Tb}$ & $<\mathrm{dl}$ & $<\mathrm{dl}$ & $<\mathrm{dl}$ & $<\mathrm{dl}$ & $<\mathrm{dl}$ & $<\mathrm{dl}$ & $<\mathrm{dl}$ & $<\mathrm{dl}$ & $<\mathrm{dl}$ & $<\mathrm{dl}$ & $<\mathrm{dl}$ & $<\mathrm{dl}$ \\
\hline Dy & 1.9 & 1.5 & 1.5 & 1.9 & 2.2 & 3.1 & 2.6 & 4.3 & 2.6 & 1.5 & 1.9 & 0.99 \\
\hline Ho & $<\mathrm{dl}$ & $<\mathrm{dl}$ & $<\mathrm{dl}$ & $<\mathrm{dl}$ & $<\mathrm{dl}$ & $<\mathrm{dl}$ & $<\mathrm{dl}$ & 0.79 & $<\mathrm{dl}$ & $<\mathrm{dl}$ & $<\mathrm{dl}$ & $<\mathrm{dl}$ \\
\hline $\mathrm{Er}$ & 1.1 & 0.9 & 0.87 & 1.2 & 1.3 & 1.7 & 1.4 & 2.4 & 1.6 & 0.99 & 1.2 & $<\mathrm{dl}$ \\
\hline $\mathrm{Tm}$ & $<\mathrm{dl}$ & $<\mathrm{dl}$ & $<\mathrm{dl}$ & $<\mathrm{dl}$ & $<\mathrm{dl}$ & $<\mathrm{dl}$ & $<\mathrm{dl}$ & $<\mathrm{dl}$ & $<\mathrm{dl}$ & $<\mathrm{dl}$ & $<\mathrm{dl}$ & $<\mathrm{dl}$ \\
\hline $\mathrm{Yb}$ & 1.0 & 0.87 & $<\mathrm{dl}$ & 1.2 & 1.3 & 1.5 & 1.3 & 2.1 & 1.6 & 0.99 & 1.1 & $<\mathrm{dl}$ \\
\hline $\mathrm{Lu}$ & $<\mathrm{dl}$ & $<\mathrm{dl}$ & $<\mathrm{dl}$ & $<\mathrm{dl}$ & $<\mathrm{dl}$ & $<\mathrm{dl}$ & $<\mathrm{dl}$ & $<\mathrm{dl}$ & $<\mathrm{dl}$ & $<\mathrm{dl}$ & $<\mathrm{dl}$ & $<\mathrm{dl}$ \\
\hline $\mathrm{Hf}$ & 0.66 & 0.07 & 0.30 & 0.98 & 0.01 & 0.01 & 0.03 & 3.9 & 2.6 & 0.19 & 0.47 & $<\mathrm{dl}$ \\
\hline $\mathrm{Ta}$ & 7.5 & 6.4 & 4.0 & 12 & 2.7 & 2.7 & 3.0 & 42 & 17 & 6.2 & 4.0 & 4.0 \\
\hline $\mathrm{W}$ & $<\mathrm{dl}$ & $<\mathrm{dl}$ & $<\mathrm{dl}$ & $<\mathrm{dl}$ & $<\mathrm{dl}$ & $<\mathrm{dl}$ & $<\mathrm{dl}$ & 1.4 & $<\mathrm{dl}$ & $<\mathrm{dl}$ & $<\mathrm{dl}$ & $<\mathrm{dl}$ \\
\hline $\mathrm{Tl}$ & $<\mathrm{dl}$ & $<\mathrm{dl}$ & $<\mathrm{dl}$ & $<\mathrm{dl}$ & $<\mathrm{dl}$ & $<\mathrm{dl}$ & $<\mathrm{dl}$ & $<\mathrm{dl}$ & $<\mathrm{dl}$ & $<\mathrm{dl}$ & $<\mathrm{dl}$ & $<\mathrm{dl}$ \\
\hline $\mathrm{Pb}$ & 8.5 & 3.2 & 7.3 & 13 & 7.0 & 5.2 & 4.6 & 7.2 & 23 & 1.2 & 0.73 & 2.8 \\
\hline $\mathrm{Th}$ & 5.5 & 3.3 & 3.9 & 9.9 & 2.1 & 2.2 & 2.0 & 6.6 & 9.9 & 2.9 & 2.5 & 0.98 \\
\hline $\mathrm{U}$ & 1.4 & 0.84 & 0.99 & 2.7 & 0.85 & 1.0 & 0.85 & 3.4 & 3.0 & 1.0 & 3.5 & 0.20 \\
\hline $\mathrm{Hg}$ & 0.15 & 0.07 & 0.15 & 0.24 & 0.13 & 0.14 & 0.09 & 0.24 & 0.56 & 0.04 & 0.03 & 0.12 \\
\hline
\end{tabular}

$<\mathrm{dl}$, below detection limit. 
Table 4 Major-element oxides (\%) and trace element concentrations $(\mu \mathrm{g} / \mathrm{g})$ of the FHS-23 Coal in the Fenghuangshan underground coal mine (on whole-coal basis).

\begin{tabular}{|c|c|c|c|c|c|c|c|c|c|c|c|c|}
\hline & FHS23- & FHS23-1 & FHS23-1 & FHS23-1 & FHS23-1 & FHS23-1 & FHS23-2 & FHS23-2 & \begin{tabular}{|l|l|}
2 & FHS23-2
\end{tabular} & FHS23-2 & \begin{tabular}{|l|l|}
2 & FHS23-2
\end{tabular} & FHS23-2 \\
\hline & $1-1$ & -2 & -3 & -4 & -5 & -6 & -1 & -2 & -3 & -4 & -5 & -6 \\
\hline $\mathrm{SiO}_{2}$ & 11.82 & 2.4 & 1.9 & 1.7 & 1.9 & 2.9 & 4.6 & 2.4 & 7.3 & 1.9 & 1.9 & 1.9 \\
\hline $\mathrm{TiO}_{2}$ & 0.30 & 0.36 & 0.25 & 0.20 & 0.12 & 0.12 & 0.24 & 0.50 & 1.0 & 0.20 & 0.20 & 0.13 \\
\hline $\mathrm{Al}_{2} \mathrm{O}_{3}$ & 1.7 & 2.9 & 1.9 & 1.7 & 2.0 & 3.0 & 1.5 & 3.4 & 6.6 & 1.7 & 1.9 & 2.1 \\
\hline $\mathrm{Fe}_{2} \mathrm{O}_{3}$ & 6.0 & 1.4 & 2.2 & 1.6 & 1.1 & 0.55 & 4.4 & 3.0 & 12 & 1.1 & 3.0 & 2.0 \\
\hline $\mathrm{MgO}$ & 0.02 & 0.03 & 0.02 & 0.02 & 0.02 & 0.04 & 0.06 & 0.30 & 0.12 & 0.02 & 0.01 & 0.02 \\
\hline $\mathrm{CaO}$ & 0.00 & 0.02 & 0.00 & 0.00 & 0.00 & 0.03 & 0.17 & 0.92 & 0.04 & 0.01 & 0.01 & 0.01 \\
\hline $\mathrm{Na}_{2} \mathrm{O}$ & 0.11 & 0.21 & 0.12 & 0.18 & 0.17 & 0.25 & 0.17 & 0.24 & 0.55 & 0.12 & 0.19 & 0.20 \\
\hline $\mathrm{K}_{2} \mathrm{O}$ & 0.17 & 0.23 & 0.18 & 0.12 & 0.12 & 0.24 & 0.14 & 0.33 & 0.74 & 0.13 & 0.10 & 0.12 \\
\hline $\mathrm{Li}$ & 43 & 106 & 76 & 70 & 75 & 112 & 67 & 58 & 80 & 61 & 77 & 81 \\
\hline $\mathrm{Be}$ & 0.85 & 1.3 & 0.20 & 0.20 & 0.85 & 1.6 & 0.77 & 0.90 & 2.4 & 0.20 & 0.20 & 0.92 \\
\hline $\mathrm{P}$ & $<\mathrm{dl}$ & 101 & $<\mathrm{dl}$ & $<\mathrm{dl}$ & $<\mathrm{dl}$ & $<\mathrm{dl}$ & 211 & $<\mathrm{dl}$ & 111 & $<\mathrm{dl}$ & $<\mathrm{dl}$ & $<\mathrm{dl}$ \\
\hline $\mathrm{Sc}$ & 2.1 & 3.0 & 2.0 & 1.4 & 0.20 & 3.9 & 1.2 & 3.5 & 7.2 & 1.7 & 1.4 & 1.6 \\
\hline $\mathrm{V}$ & $<\mathrm{dl}$ & 91 & 72 & $<\mathrm{dl}$ & $<\mathrm{dl}$ & 85 & 43 & 108 & 198 & $<\mathrm{dl}$ & $<\mathrm{dl}$ & $<\mathrm{dl}$ \\
\hline $\mathrm{Cr}$ & 10 & 17 & 13 & 9.8 & 7.8 & 11.47 & 11 & 18 & 32 & 10 & 9.5 & 9.3 \\
\hline $\mathrm{Mn}$ & 5.7 & 16 & 7.2 & 3.7 & 3.6 & 6.2 & 42 & 293 & 79 & 4.1 & 4.9 & 5.8 \\
\hline Co & 1.3 & 10 & 3.7 & 1.3 & 1.9 & 2.9 & 1.2 & 11 & 30 & 1.5 & 1.3 & 2.1 \\
\hline $\mathrm{Ni}$ & 2.1 & 13 & 7.2 & 1.4 & 1.2 & 2.0 & 1.4 & 14 & 29 & 1.8 & 1.2 & 1.8 \\
\hline $\mathrm{Cu}$ & 10 & 33 & 20 & 7.1 & 12 & 36 & 12 & 30 & 65 & 5.1 & 14 & 18 \\
\hline $\mathrm{Zn}$ & 17 & 43 & 7.9 & $<\mathrm{dl}$ & $<\mathrm{dl}$ & 16 & 9.0 & 43 & 49 & 25 & $<\mathrm{dl}$ & 16 \\
\hline $\mathrm{Ga}$ & 3.4 & 6.9 & 3.5 & 3.4 & 3.5 & 4.4 & 3.5 & 7.1 & 13 & 3.1 & 3.0 & 3.3 \\
\hline $\mathrm{Ge}$ & $<\mathrm{dl}$ & $<\mathrm{dl}$ & $<\mathrm{dl}$ & $<\mathrm{dl}$ & $<\mathrm{dl}$ & $<\mathrm{dl}$ & 0.79 & $<\mathrm{dl}$ & 1.2 & $<\mathrm{dl}$ & $<\mathrm{dl}$ & $<\mathrm{dl}$ \\
\hline As & 3.7 & 1.2 & 0.67 & 1.7 & 0.92 & $<\mathrm{dl}$ & 3.6 & 2.1 & 9.6 & 0.37 & 4.1 & 1.4 \\
\hline $\mathrm{Rb}$ & 4.7 & 6.1 & 4.4 & 2.8 & 2.9 & 5.0 & 3.0 & 7.6 & 19 & 3.0 & 2.1 & 2.8 \\
\hline $\mathrm{Sr}$ & 39 & 90 & 28 & 23 & 20 & 29 & 100 & 99 & 149 & 24 & 21 & 21 \\
\hline $\mathrm{Y}$ & 11 & 12 & 11 & 5.8 & 8.6 & 17 & 8.3 & 13 & 15 & 9.6 & 5.9 & 9.9 \\
\hline $\mathrm{Zr}$ & 70 & 90 & 63 & 51 & 41 & 69 & 64 & 105 & 238 & 47 & 49 & 49 \\
\hline $\mathrm{Nb}$ & 24 & 28 & 20 & 16 & 12 & 14 & 22 & 36 & 74 & 15 & 14 & 12 \\
\hline Mo & 3.7 & 20 & 7.0 & 1.6 & 1.1 & $<\mathrm{dl}$ & 2.6 & 26 & 25 & 2.3 & 1.6 & 1.0 \\
\hline $\mathrm{Sn}$ & 0.75 & 0.68 & 0.53 & 0.51 & 0.29 & 0.38 & 0.71 & 0.71 & 1.9 & 0.25 & 0.43 & 0.20 \\
\hline Cs & $<\mathrm{dl}$ & $<\mathrm{dl}$ & $<\mathrm{dl}$ & $<\mathrm{dl}$ & $<\mathrm{dl}$ & $<\mathrm{dl}$ & $<\mathrm{dl}$ & $<\mathrm{dl}$ & $<\mathrm{dl}$ & $<\mathrm{dl}$ & $<\mathrm{dl}$ & $<\mathrm{dl}$ \\
\hline $\mathrm{Ba}$ & 31 & 53 & 35 & 24 & 22 & 37 & 24 & 91 & 259 & 26 & 16 & 21 \\
\hline $\mathrm{La}$ & 9.8 & 20 & 11 & 9.6 & 17 & 21 & 11 & 13 & 33 & 8.2 & 9.7 & 14 \\
\hline $\mathrm{Ce}$ & 18 & 36 & 23 & 19 & 33 & 51 & 23 & 32 & 70 & 17 & 19 & 32 \\
\hline $\mathrm{Pr}$ & 1.9 & 4.0 & 2.8 & 2.0 & 3.3 & 5.7 & 2.6 & 4.0 & 8.1 & 2.0 & 2.0 & 3.5 \\
\hline $\mathrm{Nd}$ & 6.3 & 13 & 9.9 & 6.7 & 11 & 20 & 8.7 & 16 & 27 & 7.1 & 6.5 & 12 \\
\hline $\mathrm{Sm}$ & 1.4 & 3.1 & 2.0 & 1.3 & 2.2 & 4.6 & 1.8 & 4.3 & 4.8 & 1.5 & 1.4 & 2.6 \\
\hline $\mathrm{Eu}$ & 0.73 & 0.80 & 0.78 & 0.76 & 0.76 & 0.78 & 0.77 & 1.32 & 0.70 & 0.67 & 0.71 & 0.70 \\
\hline $\mathrm{Gd}$ & 1.6 & 3.0 & 2.0 & 1.3 & 2.1 & 4.3 & 1.9 & 4.5 & 4.0 & 1.6 & 1.4 & 2.5 \\
\hline $\mathrm{Tb}$ & $<\mathrm{dl}$ & $<\mathrm{dl}$ & $<\mathrm{dl}$ & $<\mathrm{dl}$ & $<\mathrm{dl}$ & $<\mathrm{dl}$ & $<\mathrm{dl}$ & $<\mathrm{dl}$ & $<\mathrm{dl}$ & $<\mathrm{dl}$ & $<\mathrm{dl}$ & $<\mathrm{dl}$ \\
\hline Dy & 1.6 & 2.4 & 1.9 & 1.2 & 1.6 & 3.6 & 1.6 & 2.9 & 3.4 & 1.6 & 1.2 & 2.0 \\
\hline Ho & $<\mathrm{dl}$ & $<\mathrm{dl}$ & $<\mathrm{dl}$ & $<\mathrm{dl}$ & $<\mathrm{dl}$ & $<\mathrm{dl}$ & $<\mathrm{dl}$ & $<\mathrm{dl}$ & $<\mathrm{dl}$ & $<\mathrm{dl}$ & $<\mathrm{dl}$ & $<\mathrm{dl}$ \\
\hline $\mathrm{Er}$ & 1.0 & 1.3 & 1.1 & 0.20 & 0.83 & 1.7 & 0.89 & 1.4 & 2.0 & 0.98 & 0.20 & 1.0 \\
\hline $\mathrm{Tm}$ & $<\mathrm{dl}$ & $<\mathrm{dl}$ & $<\mathrm{dl}$ & $<\mathrm{dl}$ & $<\mathrm{dl}$ & $<\mathrm{dl}$ & $<\mathrm{dl}$ & $<\mathrm{dl}$ & $<\mathrm{dl}$ & $<\mathrm{dl}$ & $<\mathrm{dl}$ & $<\mathrm{dl}$ \\
\hline $\mathrm{Yb}$ & 0.95 & 1.2 & 0.99 & 0.20 & 0.20 & 1.3 & 0.81 & 1.2 & 1.8 & 0.90 & $<\mathrm{dl}$ & 0.82 \\
\hline $\mathrm{Lu}$ & $<\mathrm{dl}$ & $<\mathrm{dl}$ & $<\mathrm{dl}$ & $<\mathrm{dl}$ & $<\mathrm{dl}$ & $<\mathrm{dl}$ & $<\mathrm{dl}$ & $<\mathrm{dl}$ & $<\mathrm{dl}$ & $<\mathrm{dl}$ & $<\mathrm{dl}$ & $<\mathrm{dl}$ \\
\hline Hf & 0.51 & 0.83 & 0.34 & 0.74 & $<\mathrm{dl}$ & 0.89 & 0.55 & 1.1 & 3.9 & 0.08 & 0.09 & 0.13 \\
\hline $\mathrm{Ta}$ & 3.1 & 2.9 & 2.0 & 1.6 & 0.78 & 1.9 & 3.6 & 4.1 & 9.3 & 1.6 & 1.2 & 0.93 \\
\hline $\mathrm{W}$ & $<\mathrm{dl}$ & $<\mathrm{dl}$ & $<\mathrm{dl}$ & $<\mathrm{dl}$ & $<\mathrm{dl}$ & $<\mathrm{dl}$ & $<\mathrm{dl}$ & $<\mathrm{dl}$ & $<\mathrm{dl}$ & $<\mathrm{dl}$ & $<\mathrm{dl}$ & $<\mathrm{dl}$ \\
\hline $\mathrm{Tl}$ & $<\mathrm{dl}$ & $<\mathrm{dl}$ & $<\mathrm{dl}$ & $<\mathrm{dl}$ & $<\mathrm{dl}$ & $<\mathrm{dl}$ & $<\mathrm{dl}$ & $<\mathrm{dl}$ & $<\mathrm{dl}$ & $<\mathrm{dl}$ & $<\mathrm{dl}$ & $<\mathrm{dl}$ \\
\hline $\mathrm{Pb}$ & 3.5 & 4.0 & 3.2 & 2.5 & 2.6 & 1.8 & 2.4 & 4.3 & 8.5 & 1.5 & 3.3 & 2.7 \\
\hline Th & 3.3 & 2.6 & 2.8 & 4.0 & 1.6 & 3.1 & 2.7 & 2.2 & 5.6 & 2.0 & 3.5 & 2.4 \\
\hline $\mathrm{U}$ & 1.4 & 16 & 2.5 & 1.4 & 0.20 & 1.1 & 2.8 & 17 & 8.0 & 1.0 & 1.1 & 0.85 \\
\hline $\mathrm{Hg}$ & 0.20 & 0.12 & 0.09 & 0.16 & 0.12 & 0.18 & 0.23 & 0.11 & 0.30 & 0.13 & 0.16 & 0.14 \\
\hline
\end{tabular}

$<\mathrm{dl}$, below detection limit. 
Table 5 Major-element oxides (\%) and trace element concentrations $(\mu \mathrm{g} / \mathrm{g})$ of the FHS-27 Coal in the Fenghuangshan underground coal mine (on whole-coal basis).

\begin{tabular}{|c|c|c|c|c|c|c|c|}
\hline & FHS27-1 & FHS27-2 & FHS27-3 & FHS27-4 & FHS27-5 & FHS27-6 & FHS27-7 \\
\hline $\mathrm{SiO}_{2}$ & 4.0 & 2.8 & 1.4 & 4.7 & 7.3 & 2.2 & 2.1 \\
\hline $\mathrm{TiO}_{2}$ & 0.14 & 0.19 & 0.17 & 0.28 & 0.21 & 0.13 & 0.12 \\
\hline $\mathrm{Al}_{2} \mathrm{O}_{3}$ & 1.9 & 3.0 & 2.2 & 2.9 & 2.4 & 2.2 & 2.1 \\
\hline $\mathrm{Fe}_{2} \mathrm{O}_{3}$ & 2.0 & 1.3 & 16 & 3.5 & 1.9 & 2.8 & 4.1 \\
\hline $\mathrm{MgO}$ & 0.03 & 0.05 & 0.05 & 0.08 & 0.03 & 0.04 & 0.04 \\
\hline $\mathrm{CaO}$ & 0.03 & 0.02 & 0.01 & 0.02 & 0.01 & 0.05 & 0.89 \\
\hline $\mathrm{Na}_{2} \mathrm{O}$ & 0.18 & 0.22 & 0.12 & 0.17 & 0.17 & 0.16 & 0.16 \\
\hline $\mathrm{K}_{2} \mathrm{O}$ & 0.19 & 0.29 & 0.22 & 0.41 & 0.24 & 0.24 & 0.22 \\
\hline $\mathrm{Li}$ & 45 & 62 & 33 & 30 & 43 & 43 & 33 \\
\hline $\mathrm{Be}$ & 0.83 & 2.2 & 0.76 & 1.5 & 0.90 & 1.8 & 4.1 \\
\hline $\mathrm{P}$ & 148 & $<\mathrm{dl}$ & $<\mathrm{dl}$ & $<\mathrm{dl}$ & $<\mathrm{dl}$ & $<\mathrm{dl}$ & $<\mathrm{dl}$ \\
\hline $\mathrm{Sc}$ & 0.20 & 1.7 & 0.20 & 1.2 & 1.7 & 0.20 & 1.7 \\
\hline $\mathrm{V}$ & $<\mathrm{dl}$ & $<\mathrm{dl}$ & 62 & 185 & $<\mathrm{dl}$ & $<\mathrm{dl}$ & $<\mathrm{dl}$ \\
\hline $\mathrm{Cr}$ & 8.4 & 12 & 7.1 & 33 & 11 & 7.7 & 8.8 \\
\hline $\mathrm{Mn}$ & 3.4 & 3.2 & 18 & 7.0 & 2.9 & 5.6 & 46 \\
\hline $\mathrm{Co}$ & 1.9 & 1.2 & 3.4 & 6.4 & 1.8 & 5.2 & 12 \\
\hline $\mathrm{Ni}$ & 1.5 & 1.8 & 6.7 & 12 & 1.5 & 6.2 & 20 \\
\hline $\mathrm{Cu}$ & 15 & 5.0 & 60 & 46 & 7.4 & 21 & 35 \\
\hline $\mathrm{Zn}$ & 22 & 15 & 28 & 56 & 20 & 5.6 & 8.2 \\
\hline $\mathrm{Ga}$ & 4.0 & 4.9 & 4.9 & 6.5 & 5.5 & 5.1 & 4.5 \\
\hline $\mathrm{Ge}$ & 0.82 & $<\mathrm{dl}$ & $<\mathrm{dl}$ & $<\mathrm{dl}$ & $<\mathrm{dl}$ & $<\mathrm{dl}$ & 1.4 \\
\hline As & 0.33 & 0.56 & 16 & 1.9 & 1.6 & 2.0 & 7.2 \\
\hline $\mathrm{Rb}$ & 3.2 & 6.7 & 5.4 & 10.07 & 5.5 & 5.3 & 4.0 \\
\hline $\mathrm{Sr}$ & 61 & 46 & 42 & 52 & 35 & 35 & 69 \\
\hline $\mathrm{Y}$ & 8.1 & 14 & 11 & 12 & 10 & 15 & 22 \\
\hline $\mathrm{Zr}$ & 44 & 88 & 120 & 167 & 111 & 169 & 101 \\
\hline $\mathrm{Nb}$ & 14 & 24 & 36 & 51 & 42 & 41 & 23 \\
\hline Mo & 2.4 & 2.4 & 41 & 85 & 8.4 & 3.8 & 6.7 \\
\hline Sn & 0.52 & 0.50 & 0.63 & 0.71 & 1.0 & 1.1 & 0.63 \\
\hline $\mathrm{Cs}$ & $<\mathrm{dl}$ & $<\mathrm{dl}$ & $<\mathrm{dl}$ & $<\mathrm{dl}$ & $<\mathrm{dl}$ & $<\mathrm{dl}$ & $<\mathrm{dl}$ \\
\hline $\mathrm{Ba}$ & 32 & 50 & 47 & 83 & 46 & 40 & 29 \\
\hline $\mathrm{La}$ & 8.6 & 13 & 13 & 16 & 17 & 20 & 9.0 \\
\hline $\mathrm{Ce}$ & 16 & 28 & 28 & 30 & 34 & 42 & 22 \\
\hline $\operatorname{Pr}$ & 1.9 & 3.4 & 3.7 & 3.3 & 3.6 & 4.6 & 2.7 \\
\hline $\mathrm{Nd}$ & 6.4 & 12 & 13 & 10 & 11 & 15 & 9.4 \\
\hline $\mathrm{Sm}$ & 1.5 & 2.3 & 2.1 & 2.0 & 2.2 & 2.9 & 2.3 \\
\hline $\mathrm{Eu}$ & 0.69 & 0.69 & 0.61 & 0.66 & 0.69 & 0.66 & 0.67 \\
\hline $\mathrm{Gd}$ & 1.4 & 2.2 & 2.0 & 2.1 & 2.2 & 2.9 & 2.6 \\
\hline $\mathrm{Tb}$ & $<\mathrm{dl}$ & $<\mathrm{dl}$ & $<\mathrm{dl}$ & $<\mathrm{dl}$ & $<\mathrm{dl}$ & $<\mathrm{dl}$ & $<\mathrm{dl}$ \\
\hline Dy & 1.4 & 2.3 & 2.0 & 2.3 & 1.9 & 2.5 & 3.3 \\
\hline Ho & $<\mathrm{dl}$ & $<\mathrm{dl}$ & $<\mathrm{dl}$ & $<\mathrm{dl}$ & $<\mathrm{dl}$ & $<\mathrm{dl}$ & $<\mathrm{dl}$ \\
\hline $\mathrm{Er}$ & 0.88 & 1.5 & 1.3 & 1.4 & 1.1 & 1.5 & 2.5 \\
\hline $\mathrm{Tm}$ & $<\mathrm{dl}$ & $<\mathrm{dl}$ & $<\mathrm{dl}$ & $<\mathrm{dl}$ & $<\mathrm{dl}$ & $<\mathrm{dl}$ & $<\mathrm{dl}$ \\
\hline $\mathrm{Yb}$ & 0.85 & 1.4 & 1.2 & 1.3 & 1.0 & 1.3 & 2.5 \\
\hline $\mathrm{Lu}$ & $<\mathrm{dl}$ & $<\mathrm{dl}$ & $<\mathrm{dl}$ & $<\mathrm{dl}$ & $<\mathrm{dl}$ & $<\mathrm{dl}$ & $<\mathrm{dl}$ \\
\hline $\mathrm{Hf}$ & 0.28 & 1.0 & 1.3 & 2.1 & 1.3 & 2.3 & 0.96 \\
\hline $\mathrm{Ta}$ & 1.4 & 3.2 & 2.8 & 5.4 & 5.5 & 4.0 & 1.6 \\
\hline $\mathrm{W}$ & $<\mathrm{dl}$ & $<\mathrm{dl}$ & $<\mathrm{dl}$ & $<\mathrm{dl}$ & $<\mathrm{dl}$ & $<\mathrm{dl}$ & $<\mathrm{dl}$ \\
\hline $\mathrm{Tl}$ & $<\mathrm{dl}$ & $<\mathrm{dl}$ & $<\mathrm{dl}$ & $<\mathrm{dl}$ & $<\mathrm{dl}$ & $<\mathrm{dl}$ & $<\mathrm{dl}$ \\
\hline $\mathrm{Pb}$ & 2.3 & 1.7 & 11 & 3.1 & 5.7 & 5.6 & 15 \\
\hline Th & 2.5 & 3.5 & 2.1 & 3.6 & 5.2 & 4.4 & 1.8 \\
\hline $\mathrm{U}$ & 1.4 & 2.3 & 14 & 56 & 2.1 & 1.6 & $<\mathrm{dl}$ \\
\hline $\mathrm{Hg}$ & 0.07 & 0.08 & 0.39 & 0.20 & 0.08 & 0.10 & 0.17 \\
\hline
\end{tabular}


Table 6 Averages for major-element oxides $(\%)$ and trace elements $(\mu \mathrm{g} / \mathrm{g})$ in the WJB-6, WJB-7, FHS-23 and FHS-27 Coals as well as carbonaceous mudstone (sample WJB7-1-C), together with those of western Guizhou Province coals, Chinese coals, and world hard coals for comparison (on whole-coal basis).

\begin{tabular}{|c|c|c|c|c|c|c|c|c|}
\hline & WJB-6 & WJB-7 & WJB7-1-C & FHS-23 & FHS-27 & $\begin{array}{c}\text { western Guizhou } \\
\text { Coal }^{\mathrm{a}}\end{array}$ & $\begin{array}{l}\text { Chinese } \\
\text { coal }^{\mathrm{b}}\end{array}$ & $\begin{array}{c}\text { world hard } \\
\text { coal }^{\mathrm{c}}\end{array}$ \\
\hline $\mathrm{SiO}_{2}$ & 5.7 & 11.3 & 38.3 & 3.0 & 3.5 & 9.1 & 8.5 & \\
\hline $\mathrm{TiO}_{2}$ & 0.13 & 0.20 & 1.7 & 0.30 & 0.18 & 0.36 & 0.33 & \\
\hline $\mathrm{Al}_{2} \mathrm{O}_{3}$ & 3.2 & 2.7 & 8.1 & 2.7 & 2.4 & 4.9 & 6 & \\
\hline $\mathrm{Fe}_{2} \mathrm{O}_{3}$ & 1.3 & 2.5 & 9.3 & 3.2 & 4.5 & 1.9 & 4.9 & \\
\hline $\mathrm{MgO}$ & 0.07 & 0.09 & 0.39 & 0.07 & 0.05 & 0.21 & 0.22 & \\
\hline $\mathrm{CaO}$ & 0.22 & 0.35 & 0.27 & 0.13 & 0.15 & 1.8 & 1.2 & \\
\hline $\mathrm{Na}_{2} \mathrm{O}$ & 0.17 & 0.21 & 0.27 & 0.23 & 0.17 & 0.21 & 0.16 & \\
\hline $\mathrm{K}_{2} \mathrm{O}$ & 0.12 & 0.20 & 1.11 & 0.23 & 0.26 & 0.25 & 0.19 & \\
\hline $\mathrm{Li}$ & 117 & 20 & 33 & 76 & 41 & 50 & 32 & 14 \\
\hline $\mathrm{Be}$ & $<\mathrm{dl}$ & 0.50 & 1.8 & 0.89 & 1.7 & 2.2 & 2.1 & 2 \\
\hline $\mathrm{P}$ & 103 & $<\mathrm{dl}$ & $<\mathrm{dl}$ & 161 & 148 & 201 & 400 & 250 \\
\hline $\mathrm{Sc}$ & 1.4 & 2.5 & 11 & 2.4 & 0.98 & 6.8 & 4.4 & 3.7 \\
\hline $\mathrm{V}$ & 24 & 19 & 136 & 109 & 123 & 123 & 35 & 28 \\
\hline $\mathrm{Cr}$ & 6.9 & 8.6 & 74 & 13 & 13 & 32 & 15 & 17 \\
\hline $\mathrm{Mn}$ & 8.8 & 26 & 52 & 49 & 12 & 169 & 116 & 71 \\
\hline Co & 4.5 & 1.5 & 18 & 5.9 & 4.5 & 14 & 7.1 & 6 \\
\hline $\mathrm{Ni}$ & 4.0 & 1.8 & 25 & 6.0 & 7.1 & 37 & 14 & 17 \\
\hline $\mathrm{Cu}$ & 19 & 11 & 35 & 22 & 27 & 61 & 18 & 16 \\
\hline $\mathrm{Zn}$ & 18 & 12 & 30 & 26 & 22 & 55 & 41 & 28 \\
\hline $\mathrm{Ga}$ & 5.0 & 4.9 & 13 & 4.9 & 5.0 & 13 & 6.6 & 6 \\
\hline $\mathrm{Ge}$ & $<\mathrm{dl}$ & $<\mathrm{dl}$ & 1.1 & 1.0 & 1.1 & $<\mathrm{dl}$ & 2.8 & 2.4 \\
\hline As & 2.3 & 5.4 & 7.8 & 3.0 & 4.2 & 3.9 & 3.8 & 9 \\
\hline $\mathrm{Rb}$ & 2.3 & 3.5 & 27 & 5.4 & 5.7 & 13 & 9.3 & 18 \\
\hline $\mathrm{Sr}$ & 97 & 96 & 255 & 54 & 48 & 135 & 140 & 100 \\
\hline $\mathrm{Y}$ & 11 & 8.5 & 20 & 10 & 13 & 24 & 18 & 8.2 \\
\hline $\mathrm{Zr}$ & 41 & 68 & 234 & 79 & 114 & 224 & 90 & 36 \\
\hline $\mathrm{Nb}$ & 16 & 24 & 125 & 24 & 33 & 14 & 9.4 & 4 \\
\hline Mo & 1.0 & 3.4 & 2.0 & 7.7 & 21 & 8.2 & 3.1 & 2.1 \\
\hline $\mathrm{Sn}$ & $<\mathrm{dl}$ & $<\mathrm{dl}$ & $<\mathrm{dl}$ & $<\mathrm{dl}$ & 0.48 & 5.9 & 2.1 & 1.4 \\
\hline Cs & $<\mathrm{dl}$ & $<\mathrm{dl}$ & 1.0 & $<\mathrm{dl}$ & $<\mathrm{dl}$ & 0.84 & 1.1 & 1.1 \\
\hline $\mathrm{Ba}$ & 39 & 81 & 320 & 58 & 47 & 119 & 159 & 150 \\
\hline $\mathrm{La}$ & 12 & 11 & 26 & 15 & 14 & 32 & 23 & 11 \\
\hline $\mathrm{Ce}$ & 25 & 23 & 56 & 33 & 29 & 60 & 46.7 & 23 \\
\hline $\operatorname{Pr}$ & 2.8 & 2.6 & 6.5 & 3.7 & 3.3 & 7.9 & 6.4 & 3.4 \\
\hline $\mathrm{Nd}$ & 9.7 & 8.7 & 22 & 13 & 11 & 23 & 22 & 12 \\
\hline $\mathrm{Sm}$ & 2.2 & 1.8 & 4.3 & 2.7 & 2.2 & 4.4 & 4.1 & 2.2 \\
\hline $\mathrm{Eu}$ & 0.64 & 0.62 & 1.1 & 0.79 & 0.67 & 0.77 & 0.84 & 0.43 \\
\hline $\mathrm{Gd}$ & 2.1 & 1.7 & 4.3 & 2.6 & 2.2 & 4.7 & 4.7 & 2.7 \\
\hline $\mathrm{Tb}$ & $<\mathrm{dl}$ & $<\mathrm{dl}$ & $<\mathrm{dl}$ & $<\mathrm{dl}$ & $<\mathrm{dl}$ & 0.64 & 0.62 & 0.31 \\
\hline Dy & 2.1 & 1.7 & 4.3 & 2.1 & 2.2 & 3.4 & 3.7 & 2.1 \\
\hline Ho & $<\mathrm{dl}$ & $<\mathrm{dl}$ & 0.8 & $<\mathrm{dl}$ & $<\mathrm{dl}$ & 0.7 & 0.96 & 0.57 \\
\hline $\mathrm{Er}$ & 1.2 & 1.3 & 2.4 & 1.0 & 1.5 & 1.8 & 1.8 & 1 \\
\hline $\mathrm{Tm}$ & $<\mathrm{dl}$ & $<\mathrm{dl}$ & $<\mathrm{dl}$ & $<\mathrm{dl}$ & $<\mathrm{dl}$ & 0.26 & 0.64 & 0.3 \\
\hline $\mathrm{Yb}$ & 1.2 & 1.2 & 2.1 & 0.91 & 1.4 & 2 & 2.1 & 1 \\
\hline $\mathrm{Lu}$ & $<\mathrm{dl}$ & $<\mathrm{dl}$ & $<\mathrm{dl}$ & $<\mathrm{dl}$ & $<\mathrm{dl}$ & 0.31 & 0.38 & 0.2 \\
\hline $\mathrm{Hf}$ & 0.29 & 1.1 & 3.9 & 0.93 & 1.3 & 4.3 & 3.7 & 1.2 \\
\hline $\mathrm{Ta}$ & 5.4 & 7.9 & 42 & 2.8 & 3.4 & 0.84 & 0.62 & 0.3 \\
\hline $\mathrm{W}$ & $<\mathrm{dl}$ & $<\mathrm{dl}$ & 1.4 & $<\mathrm{dl}$ & $<\mathrm{dl}$ & 0.93 & 1.1 & 0.99 \\
\hline $\mathrm{Tl}$ & $<\mathrm{dl}$ & $<\mathrm{dl}$ & $<\mathrm{dl}$ & $<\mathrm{dl}$ & $<\mathrm{dl}$ & 0.11 & 0.47 & 0.58 \\
\hline $\mathrm{Pb}$ & 7.0 & 7.0 & 7.2 & 3.3 & 6.4 & 15 & 15 & 9 \\
\hline Th & 4.1 & 4.1 & 6.6 & 3.0 & 3.3 & 6.5 & 5.8 & 3.2 \\
\hline $\mathrm{U}$ & 1.2 & 1.9 & 3.4 & 3.8 & 13 & 14 & 2.4 & 1.9 \\
\hline $\mathrm{Hg}$ & 0.14 & 0.19 & 0.24 & 0.17 & 0.15 & 0.09 & 0.16 & 0.1 \\
\hline
\end{tabular}

$<$ dl, below detection limit; a, Dai et al. (2005); b, Dai et al. (2012a); c, Ketris and Yudovich (2009). 